\title{
Molecular and Cellular Analysis of Disease Resistance Mechanisms in Wheat
}

\author{
By \\ Ashwaq Omar Albaraky \\ Bachelor Degree - Princess Norah Bint Abdul Rahman University, 2008
}

A thesis submitted to the Faculty of Graduate and Postdoctoral Affairs in partial fulfillment of the requirement for the degree of Master of Science in Biology

\author{
Carleton University \\ Ottawa, Ontario, Canada
}

(C) 2013 


\section{ACKNOWLEDGEMENTS}

First of all, I thank my supervisor Dr. Tim Xing for accepting me in his lab. I do not know how much I thank you Dr. Xing for everything that you have done for my graduate study. Thank you for your patience, enthusiasm, incredible supervision, and encouragement throughout my graduate study. Thank you for your confidence in me.

Moreover, I also would like to thank Dr. Doug Johnson and Dr. Ashkan Golshani, who were my advisory committee members, for their invaluable suggestions and comments. Thank you to the members of the Xing lab, specifically to Yasamin Al-Rewashdy for her encouragement.

I also thank my lovely parents Mr.Omar Al-Baraky and Mrs. Rahmah Al-Baraky for supporting me throughout my years of graduate study. I also thank them for their patience despite of the distance that separates us. I wish to tell them that they are always in my heart.

Furthermore, I thank my husband Mr.Abdulaziz Al-Shahri and my daughter for their love, support, and patience throughout my graduate study.

Finally, I would like to thank King Abdullah Bin Abdulaziz Al-Saud, King of Saudi Arabia, for giving me a scholarship to study abroad. A thank you note goes to the Ministry of Higher Education and Saudi Cultural Bureau for their cooperation. 


\begin{abstract}
Many abiotic stresses such as drought, high salinity, high or low temperatures, and biotic stresses such as insect attacks or pathogen infection affect plant growth and development. Plants have developed specific mechanisms to detect external signals with proper physiological responses in order to survive under these challenges. In order to respond to these effects, many pathways are activated and protein phosphorylation is required for this activation. One of the phosphorylation pathways is mitogen activated protein kinase (MAPK) pathway. The MAPK pathway consists of at least three enzymes including MAPK, MAPK kinase (MAPKK), and MAPK kinase kinase (MAPKKK). MAPK is activated by MAPKK, which is in turn activated by a MAPKKK. In response to abiotic and biotic stresses, programmed cell death (PCD) may also be triggered. In this study, we have examined PCD in wheat (Triticum aestivum) leaves from a susceptible and a resistant cultivar to Fusarium head blight. The results have shown that there was cell death in wheat, which appeared to be necrosis and associated with concurrent accumulation of reactive oxygen species (ROS). Furthermore, a set of DNA repairing genes has been studied by RT-PCR including RAD50, RAD51, and MSH2. Our results have indicated that RAD50 and RAD51 could be involved in DNA damage repairing in wheat leaves when treated with fungal toxin Fumonisin B1 (FB1) or plant defense signaling molecule salicylic acid (SA). However, there was no change at transcriptional level for $\mathrm{MSH} 2$, indicating that some DNA repairing genes may work at protein level with other components in the DNA repairing system. $\beta$-1, 3-glucanase (a defense enzyme) and glutamine synthetase (a vegetative growth related enzyme) have been studied. There was no change in the enzyme activities after FB1 or SA treatment. We have also examined FLR (a MAPKKK) gene expression by RT-PCR. Its
\end{abstract}


transcript level was not changed by either SA or FB1 treatment. Our work may contribute to the development of a strategy to manipulate wheat disease resistance. 


\section{TABLE OF CONTENTS}

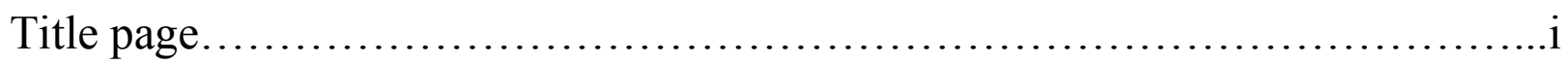

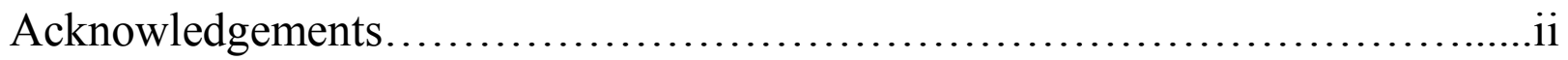

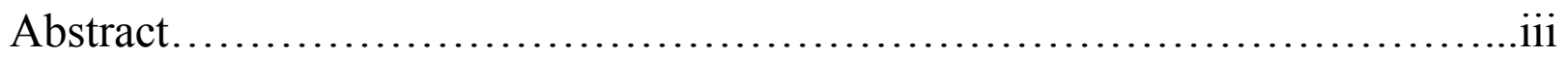

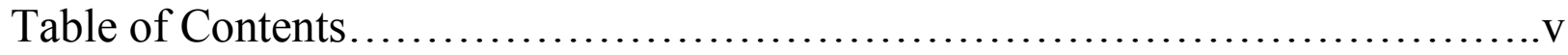

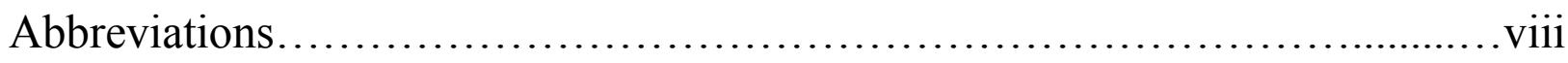

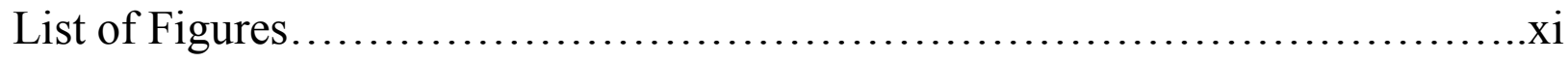

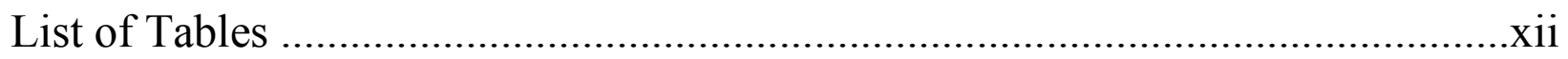

Chapter I General Introduction..................................................

1.1. Protein phosphorylation ........................................................................

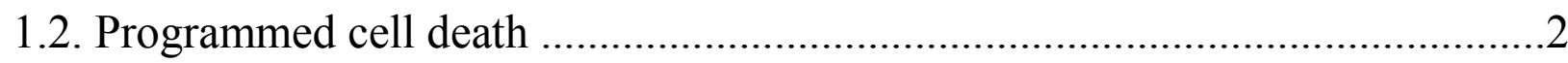

1.2.1. DNA ladders .....................................................................................

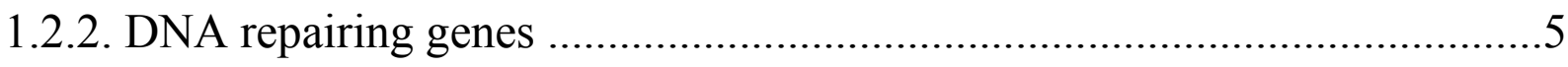

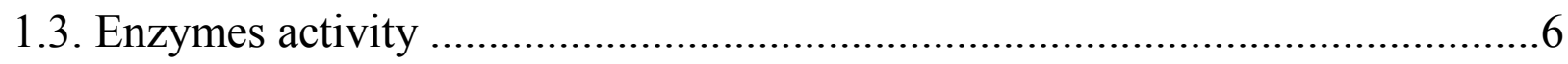

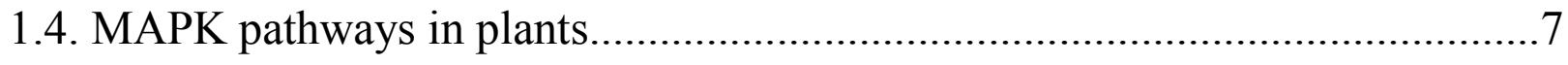

1.5. Wheat (Triticum aestivum) project..................................................................11

Chapter II Methods and Materials...................................................

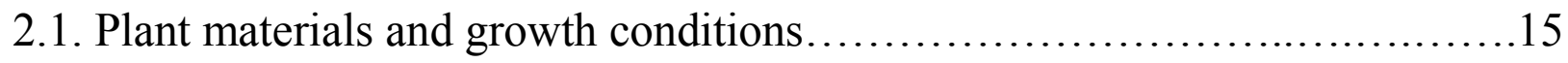

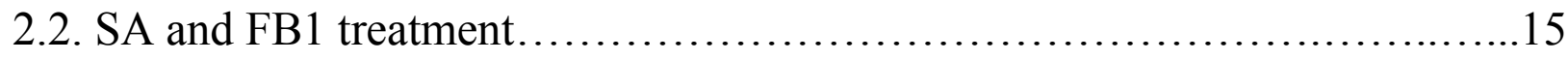


2.3. Programmed cell death............................................... 16

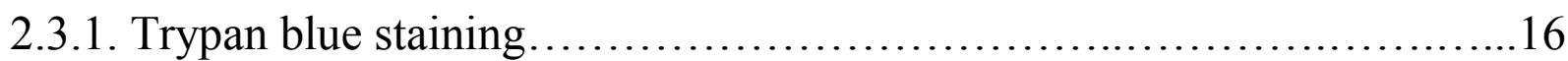

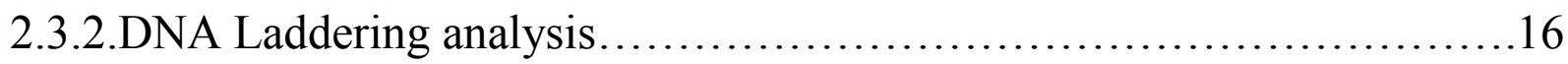

2.3.3. Expression analysis of DNA repairing genes.............................17

2.4. Expression analysis of FLR gene by RT-PCR .............................. 18

2.5. $\beta$-1, 3-glucanase assay .............................................................................. 18

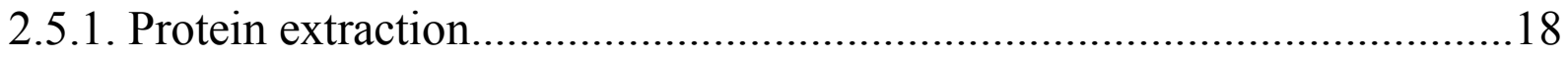

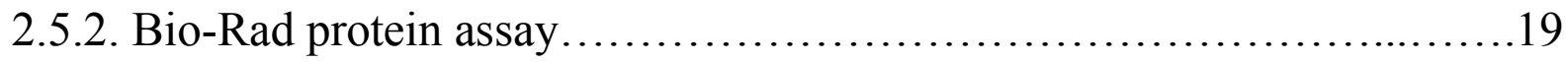

2.5.3. $\beta$-1,3-glucanase assay..........................................................................19

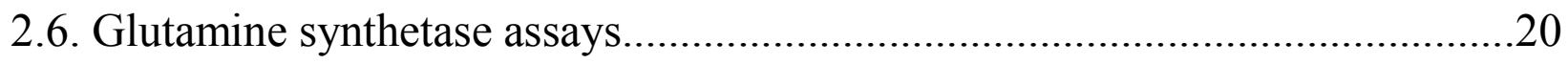

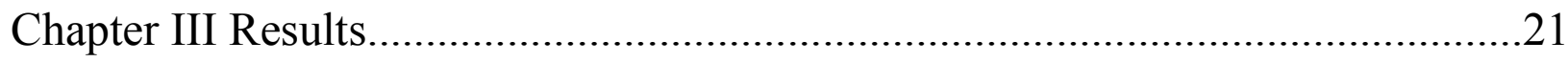

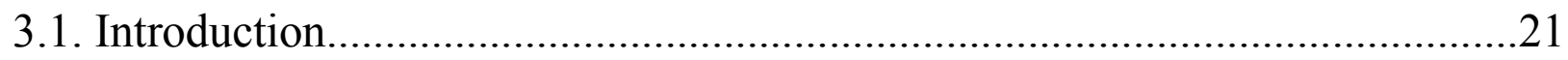

3.2. SA and FB1 induced cell death in Frontana and Roblin.....................23

3.3. SA and FB1 treatment and DNA ladders in Roblin and Frontana.............36

3.4. Expression of DNA repairing genes in wheat leaves treated with

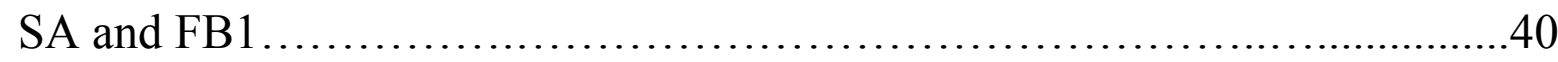

3.4.1. Radiation sensitive 50 (RAD 50) and RAD 51........................40

3.4.2. MSH2 mismatch repairing gene expression............................40

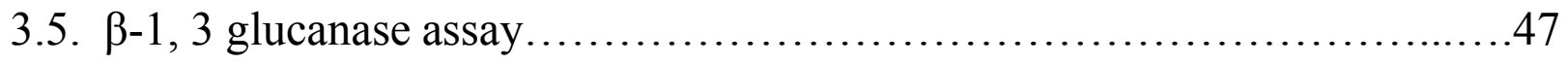

3.6. Glutamine synthetase assay ............................................... 49

3.7. SA and FB1 effects on FLR.................................................

Chapter IV Discussion, Conclusion and Future Work.................................55 
4.1. SA and FB1 induce cell death and programmed cell death in wheat..........55

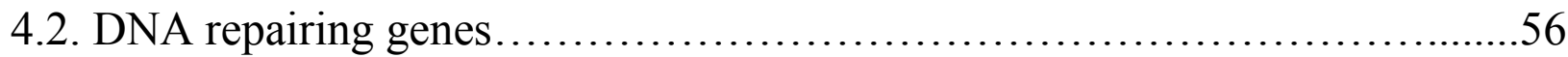

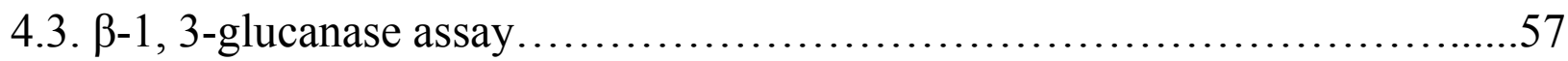

4.4. Glutamine synthetase ..............................................5

4.5 FLR gene........................................................... 58

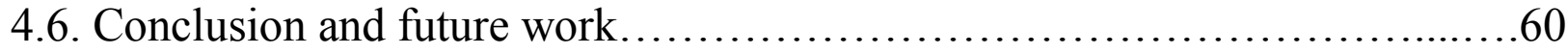

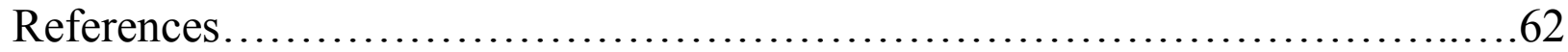




\section{ABBREVIATIONS}

Avr: avirulence

ATM: ataxia telangiectasia mutated

ATR: ATM and Rad3 related

BTH: benzothia diazole

CC-NB-LRR: coiled coil nucleotide binding leucine-rich repeat

DAMPs: danger-associated molecular patterns

Dmc1: meiosic-specific homolog

DON: deoxynivalenol

DSBs: double-strand DNA breaks

DTT: dithiothneitol

ET: ethylene

FB1: fumonisin B1

FHB: fusarium head blight

FLR: fusarium leaf rust

GAPDH: glyceraldehyde-3-phosphate dehydrogenase

GS: glutamine synthetase

HCL: hydroxylamine

HR: hypersensitive response

JA: jasmonic acid

LRR: leucine-rich repeat

MAPK: mitogen-activated protein kinase

MAPKK: mitogen-activated protein kinase kinase

MAPKKK: mitogen-activated protein kinase kinase kinase 
MAMPs: microbe associated molecular patterns

MMR: mismatch repair

MRE 11: meiotic recombination 11

MRN: Mre1 1-Rad51-Nbs1

NADPH: key enzyme in ROS productions

NB: nucleotide binding domain

NbMKK1: Nicotiana benthamiana mitogen activation protein kinase kinase 1

NBS1: Nijmegen breakage syndrome 1

NHEJ: nonhomologous end-joining

OsBIMK1: Oryza sativa L BTH-induced MAPK1

PAMPS: pathogen associated molecular pattrens

PCD: programmed cell death

PCR: polymerase chain reaction

PIKK: phosphatidylinositol 3-kinase-related kinases

PKC: protein kinase c

PMSF: phenylmethanesulfonyl fluoride

PR: pathogenesis-related gene

PRRs: pattern recognition receptors

RAD50: radiation sensitive 50

RAD51: radiation sensitive 51

ROS: reactive oxygen species

RT-PCR: reverse-transcriptase polymerase chain reaction

$\mathrm{R}$ : resistance

SA: salicylic acid 
SAR: systemic acquired resistance

SIRK: SA-induced protein kinase

TCA: trichloroacetic acid

TEA: triethanolamine

TIR-NB-LRR: Drosphila toll and human interleukin 1 receptor

WIPK: wound-induced protein kinas 


\section{LIST OF FIGURES}

\section{Chapter 1}

Figure 1-1: The final effectiveness of MAPK pathway in plants defense is controlled by dynamic regulatory mechanisms 9

Figure 1-2: Overview of my project on wheat MAPK pathways genes....................14

Chapter 3

Figure 3-1: Light Microscopy images of Frontana and Roblin leaves........................24

Figure 3-2: Images of Frontana and Roblin leaves.................................... 31

Figure 3-3: Wheat leaf DNA smearing after SA and FB1 treatments........................37

Figure 3-4: DNA repairing genes expression on wheat leaves treated with SA and FB1.......42

Figure 3-5: $\beta$-1,3-glucanase enzyme activity in Roblin and Frontana wheat leaves.............48

Figure 3-6: Glutamine synthetase activity in Roblin and Frontana wheat leaves..............50

Figure 3-7: Effect of SA and FB1 on FLR gene expression.........................52 


\section{LIST OF TABLES}

Table 3-1: The comparison of cell death measured using trypan blue in Roblin and Frontana

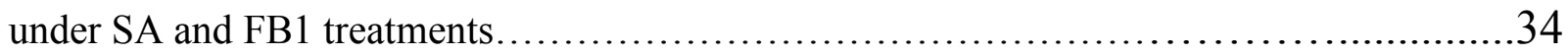

Table 3-2: DNA repairing genes with their GenBank accession numbers.............46 


\section{Chapter I}

\section{General Introduction}

Plants are affected by biotic stresses such as insect attack or pathogen infection, or by abiotic stresses such as drought, high or low temperatures, or high salinity. Plants have developed specific mechanisms to detect external signals with proper physiological responses in order to survive under these challenges (Bohnert et al., 1995).

\subsection{Protein Phosphorylation}

Protein phosphorylation is one of the crucial post-translational modifications, and it plays important roles in plant growth and development (Luan, 2002). Also, it is a step to regulate some protein kinases and to modify enzymes for catalysis (Newton, 2003). Protein stability, biological activity, cellular location, and its interaction with other proteins can be changed by phosphorylation (Xing et al., 2002). Protein phosphorylation is involved in plant response to pathogen attack (Xing et al., 2002), and it is one of the earliest events during plant-pathogen interactions (Xing and Laroche, 2011). For instance, oxidative burst, which involves releasing of reactive oxygen species (ROS), is considered one of the ways that is used in plant defense mechanisms (Xing et al., 2002). NADPH oxidase, a key enzyme in ROS production, consists of three cytosolic subunits and two plasma membrane subunits in mammalian cells (Xing and Jordan, 2000). It remains unfunctional until the cytosolic components are phosphorylated by protein kinase $\mathrm{C}$ ( $\mathrm{PKC})$ and form a complex with the plasma membrane components (Xing and Jordan, 2000). The final effectiveness of defense mechanisms can be determined by the collective effect of complex phosphorylation machinery. In Arabidopsis, there are about 200 phosphatase genes and 1000 protein kinase 
genes (Arabidopsis genome initiative, 2000). In the past few decades, many kinases, phosphates, and other molecules that are involved in phosphorylation pathways have been studied (Zhang and Klessig, 2001; Xing et al., 2002; Xing and Laroche, 2011).

\subsection{Programmed Cell Death}

One of the physiological cell death processes involved in selective elimination of undesirable cells is programmed cell death (PCD) (Ellis et al., 1991). Plant and animal cells may have resemblance in some functions. In animal cells, the apoptosis is similar to hypersensitive response (HR) process in plant cells during plant-pathogen interactions (Lam et al., 2001). Some characteristics of cell death are shared by plants and animals (Watanabe and Lam, 2006).

Plants and animals respond to pathogen infection through programmed cell death. During immune responses, plants and animals have specific characters of cell death; however, the immunity system is diverse. Pathogens can penetrate the layers of host defense leading to disease expansion. Plant cells are more complicated than animals to a certain extent; for example, it is enclosed with a rigid cell wall which leads to the evolution of a primary cellautonomous immune system (Coll et al., 2011). In plants and animals, the first line of defense that triggers immune signaling and recognizes microbe associated molecular patterns (MAMPs) or danger associated molecular patterns (DAMPs) is provided by pattern recognition receptors (PRRs) (Coll et al., 2011). Considerable progress has been made in the research of molecular mechanisms of cell death process in animals and plants.

In all living cells from prokaryotes to eukaryotes, PCD is recognized as a universal cellular suicide process (Beers and McDowell, 2011). There are three main PCD research areas: 
terminal differentiation, disease resistance, and senescence (Jones, 2001). PCD plays an essential role in disease resistance, cell and tissue specialization, and tissue sculpting, and cell death occurs in diverse plant tissue (Jones, 2001; Greenberg and Yao, 2004). Some factors can induce cell death such as heat shock (Fan and Xing, 2004), leaf senescence (Munne-Bosch and Alegre, 2004), and water stress (Duan et al., 2010). During pathogen attack, localized cell death arises in immune plants and susceptible plants. In resistant plants, a pathogen avirulence (Avr) gene product is detected by a host resistance (R) protein, triggering a hypersensitive response, which leads to localized programmed cell death (Pozo et al., 2004). During this process, in addition to the production of ROS, changes in ion fluxes, activation of MAPK cascades, and proteolysis may also occur (Xing and Jordan, 2000). For necrotrophic pathogens, the host cells are killed by the activated host PCD or the injected toxins, and on the other hand, pathogen spread can be limited by early activation of host PCD for biotrophic pathogens (Pozo et al., 2004).

During the plant-pathogen interaction, MAPKs are involved in cell death regulation (Pozo et al., 2004; Yang et al., 2001; Zhang and Liu, 2001). In tobacco, two MAPKs, wound-induced protein kinase WIPK and SA-induced protein kinase SIRK, are regulated by the upstream NtMEK2, a MAPKK (Yang et al., 2001). The expression of many defense genes, ROS generation and HR-like cell death were all activated by the active mutant of NtMEK2 through the endogenous WIPK and SIPK (Yang et al., 2001). Another kinase that has been identified in tomato as a positive regulator associated with plant disease and immunity is MAPKKK $\alpha$ that is a MAPKKK (Pozo et al.,2004). Furthermore, a high throughput overexpression screen of Nicotiana benthamiana cDNAs has verified that NbMKK1, a MAPKK, is a potent inducer of HR-like cell death (Takahashi et al., 2007). ROS plays a role between PCD and MAPK 
cascades. ROS can activate callose and lignin deposition and attempt to block the pathogen by supporting cell walls in response to pathogen attack (Pontier et al., 1998). Thus, in plants, another significant feature of PCD is the callose deposition.

Fungal toxin is often applied to cell death studies as it often provides a pathogen-free system. Of the toxins, Fumonisin B1 (FB1) has been applied to Arabidopsis (Asia et al., 2000; Plett et al., 2009) and wheat (Gao, 2011). FB1 induces programmed cell death in plants and animals (Asai et al., 2000). In animal cells, FB1 treatment causes nuclear DNA fragmentation leading to apoptosis; and in Arabidopsis, the treatment causes the loss of membrane integrity (Asai et al., 2000). Studies have also indicated that FB1 regulates plant defense reactions at transcriptional, and post-translational (reversible protein phosphorylation) levels (Asai et al., 2000; Plett et al., 2009; Fan et al., 2009). Asai et al. (2000) and Plett et al. (2009) have indicated that FB1 induced cell death in Arabidopsis protoplasts or plants may involve SA, jasmonic acid (JA) and ethylene (ET) signaling pathways.

\subsubsection{DNA ladders}

During PCD in plant and animal cells, specific DNA fragmentation into DNA laddering or oligonucleosomal units occurs (Danon et al., 2000). Nuclease activities cause necrosis and DNA smear on agarose gels (Wyllie et al., 1980). Many studies have described DNA damage under various environmental stresses such as heat (Balk et al., 1999; Swidzinski et al., 2002) and cold (Koukalovā et al., 1997). Danon et al. (2000) suggested that DNA ladders are used at the molecular level to discriminate apoptosis from necrosis.

DNA damage can be triggered by cellular metabolism products such as reactive radicals or by the action of exogenous agents such as radiation and chemicals mutagens (Rich et al., 
2000). The breaks of DNA lead to chromosomal translocations and rearrangements, cell death, and senescence (Rich et al., 2000).

\subsubsection{DNA repairing genes}

In order to respond to DNA damage, cells activate complex signaling pathways that regulate DNA repairing and cell cycle arrest (Shiloh, 2006; Cimprich and Cortez, 2008). These processes depend on the function of some proteins (Shiloh, 2006; Cimprich and Cortez, 2008). Protein kinases are involved as regulators in DNA damage response. For example, protein kinase ataxia telangiectasia mutated (ATM), and ATM and Rad3 related (ATR) are activated in a diverse category of damage. ATR belongs to the family of phosphatidylinositol 3-kinase-relatedkinase (PIKK). ATM is activated in response to the presence of double-strand DNA breaks (DSBs). Multiple events occur to preserve genomic integrity such as cell cycle arrest, chromatin

remodeling, DNA repair, and cell death when ATR is triggered (Amiard et al., 2010). Mre1 1Rad50-Nbs1 (MRN) complex is also involved in DNA damage repair, DNA replication, meiosis, and telomere maintenance, and it consists of Meiotic recombination 11 (MRE11), Nijmegen Breakage Syndrome 1 (NBS1), and radiation sensitive 50 (Rad50) (Czornak et al., 2008; Lamarche et al., 2010). RAD50-Mre11-Xrs2 complex is essential for replication of telomere and preparation of DNA ends for telomerase (Gallego and White, 2001). Double strand breaks may cause rearrangements such as deletion, duplications, insertions, and reciprocal translocation when misrepaired (Schubert et al., 2004). DSBs are repaired by nonhomologous end-joining (NHEJ) or by homologous recombination. An intact homologous duplex is needed by homologous recombination to form heteroduplex for repairing the damage site (Barzel and Kupiec, 2008). 
During meiosis, some other proteins are expressed such as RAD51 (Czornak et al., 2008; Lamarche et al., 2010). The first discovered RAD51 was from Saccharomyces cerevisiae (Bishop et al., 1992). RAD51 gene exists in tomato and Arabidopsis as a single copy, while maize and Physcomitrella patens contain two copies (Devisetty et al., 2010). RAD51 and Dmc1 are required for many mitotic homologous recombination events (Smith and Nicholas, 1998; Devisetty et al., 2010). RAD51 and Dmc1 play important roles in homology search, binding of single stranded DNA, and strand invasion (Devisetty et al., 2010). RAD51 protein forms a nucleofilament with ATP-dependant strand-exchange activity, which has roles in meiosis, DSB repair, and homologous recombination (Devisetty et al., 2010).

Mismatch repair (MMR) system has a significant character in its participation in response to DNA damage (Stojic et al., 2004), promoting genetic stability by repairing DNA replication errors (Kornberg and Bake, 1992; Modrich and Lahue, 1996), preventing productive meiosis in interspecies hybrids (Hunter et al., 1996), and inhibiting recombination between divergent DNA sequences (Petit et al., 1991). The plant $M S H$-like genes are involved in the maintenance of genome stability (Emmanuel et al., 2006). For example, AtMshl is involved in the maintenance of mitochondrial genome stability (Abdelnoor et al., 2003), and AtMsh2 is involved in the repair of replication errors (Leonard et al., 2003; Depegies et al., 2005).

\subsection{Enzymes activity}

The enzyme $\beta$-1, 3-glucanase and glutamine synthetase (GS) were selected. A fungal cell wall is composed of polysaccharides $\beta$-glucans, chitin, and mannans. The structure of the fungal cell wall is a branched $\beta$-1, 3-glucan cross-linked to chitin. In plant-fungus interactions, fungal specific molecules such as cell membrane sterols and cell wall polysaccharides can be recognized by the plants as pathogen associated molecular patterns (PAMPs) through 
pattern recognition receptors (PRRs) (Fujikawa et al., 2012). During plant defense response, $\beta-1,3$-glucan linker in fungal cell wall is hydrolyzed by the induced plant $\beta-1,3$-glucanase.

Overexpressing $\beta$-1, 3-glucanase gene increased resistance against fungal pathogens (Liu et al., 2009).

Glutamine synthetase (GS) is involved in the reassimilation of ammonium released by many processes such as deamination of amino acids, protein catabolism, and photorespiration (Seabra et al., 2010). During plant growth and development, nitrogen can be assimilated with the action of glutamine synthetase, forming glutamine. Transgenic approach has been applied in the attempt to enhance GS activity and to improve nitrogen assimilation (Man et al., 2011; Seabra et al., 2010). Ectopic expression of bacterial glutamine dehydrogenate in transgenic tobacco and corn was the main focus in order to enhance nitrogen utilization (Mungur et al., 2005), resulting in the ammonium incorporation into glutamine (Man et al., 2011). Some purine bases for nucleic acid biosynthesis, for the synthesis of a number of essential coenzymes, and for the biosynthesis of signaling molecules, are provided by the intermediate products of this pathway (Man et al., 2011).

\subsection{MAPK pathways in plants}

One of the principal phosphorylation pathways that are used by plants in biotic and abiotic stress responses is mitogen-activated protein kinase (MAPK) pathway, which consists of MAPKKK, MAPKK, and MAPK (Cvetkovska et al., 2005). MAPKKK activates the downstream MAPKK, and MAPKK activates MAPK, then, MAPK activates downstream transcriptional factors (Cvetkovska et al., 2005). The general composition of an MAPK pathway is: 


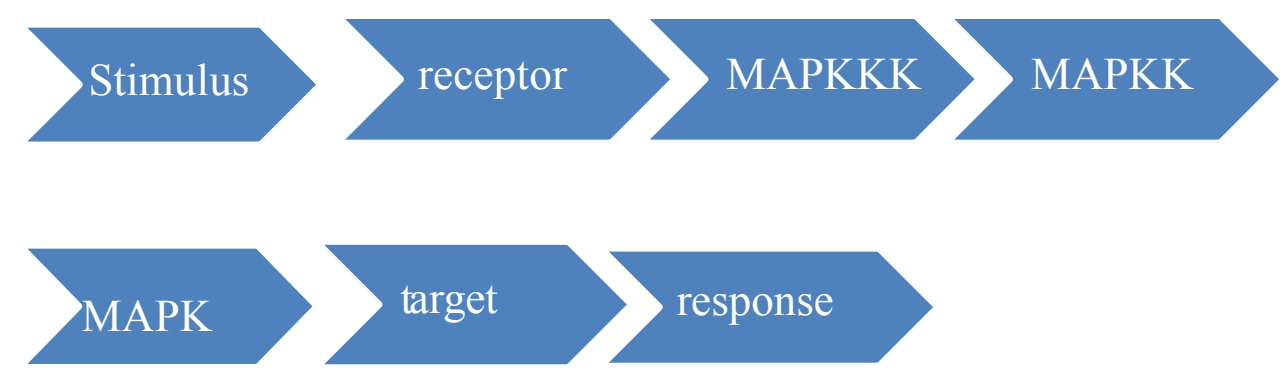

Many kinases themselves can be regulated at transcriptional, translational, and posttranslational levels. Generally, kinase functions can be analyzed at transcriptional level and by motif modifications in amino acid sequence (Cvetkovska et al., 2005).

Recent studies have shown that in Arabidopsis genome, there are 60 MAPKKKs, 10 MAPKKs, and 20 MAPKs (Xing et al., 2002). There are 15 MAPK genes in rice and 21 MAPK genes in poplar (Hamel et al., 2006). Also, rice families are smaller than poplar (Hamel et al., 2006). OsMAPK5 is one of the MAPK genes in rice, and it consists of OsMAPK5a and OsMAPK5b (Xiong and Yang, 2003). OsMAPK5 is regulated in roots when there is drought, high salinity, or low temperature (Xiong and Yang, 2003). OsMAPK5a belongs to the plant MAPK family A1 subgroup (Ichimura et al., 2002). It is 1396 bp long and contains all subdomains that are preserved between all MAPK families (Hirt, 1997). In rice, OsMAPK5a is involved abscisic acid, SA or JA pathways (Xiong and Yang, 2003).

Different approaches have been taken to improve plant resistance to pathogen infections. Previously in our lab tMEK2, a tomato MAPKK, was overexpressed in wheat and it enhanced wheat resistance to leaf rust (Gilbert et al., 2006). One of the most common diseases in rice is bacterial blight, which is caused by Xanthomonas oryzae PV. Oryzae (Yuan et al., 2007). By suppressing OsMPK6, the rice enhanced resistance to different pathogens 
(Yuan et al., 2007). In Arabidopsis, activation of AtMPK3 and AtMPK6 can increase disease resistance (Zhang and Klessig, 2001; Asia et al., 2002). In tobacco, activation of NtWIPK (wound-induced protein kinase) and NtSIPK (SA-induced protein kinase) also enhanced disease resistance (Yuan et al., 2007). In tomato, LeMPK2 and LeMPK3 are activated during plant response to pathogen attacks (Pedley and Martin, 2004). MAPK pathways are involved in changing redox chain activities, hypersensitive response, cell death, generation of (ROS), systemic acquired resistance (SAR), activation of pathogenesis-related $(P R)$ genes, and other protective genes (Figure1-1).

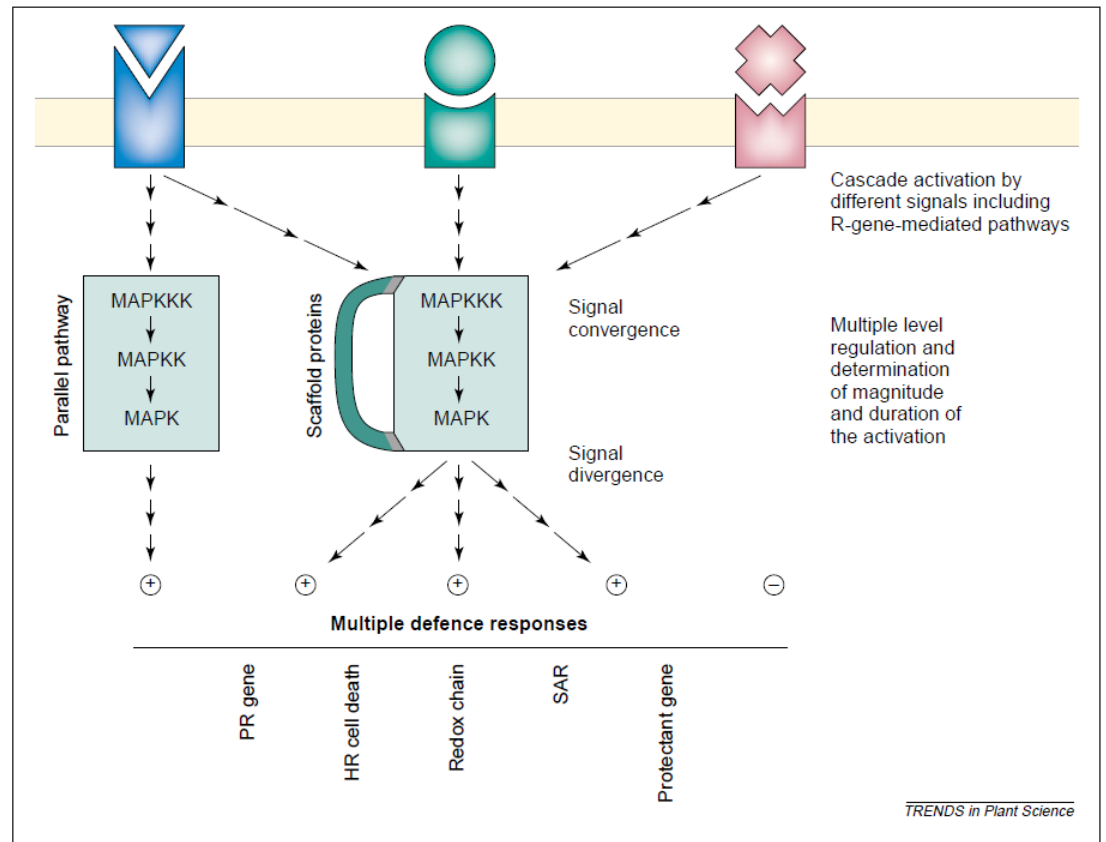

Figure 1-1: The final effectiveness of MAPK pathway in plants defense is controlled by dynamic regulatory mechanisms (Xing et al., 2002).

Figure 1-1 shows how MAPK is regulated and how it regulates its downstream activities in plant defense. Multiple MAPK cascades can be regulated in parallel pathways 
by a single stimulus (Xing et al., 2002).

Cascades are able to respond to stimulus within minutes since MAPK components are associated with each other by scaffold proteins (Xing et al., 2002). HR-like cell death, redox chain, SAR, and PR represent some major downstream responses in an MAPK cascade (Xing et al., 2002). In rice, MAPKs are important in defense signal transduction (Liberherr et al., 2005; Reyna and Yang, 2006). Some of the well-studied rice MAPKs include OsMAPK1, OsMAPK2, OsMAPK4, OsMAPK6, OsMAPK7, OsMAPK8, OsMAPK13, OsMAPK15, and OsMAPK17 (Liberherr et al., 2005; Reyna and Yang, 2006). Another vital rice MAPK is OsBIMK1 (Oryza sativa L BTH-induced MAPK1), which was activated by biological and chemical treatment or pathogen attacks such as benzothia diazole (BTH), dichloroisonicotinic acid, probenzole, JA, and wounding (Song and Goodman, 2002). Overexpression of rice OsMAPK6 improved disease resistance (Yuan et al., 2007). BWMK1, another rice MAPK, is activated by a fungal elicitor (Cheong et al., 2003). When BWMK1 was overexpressed, $P R$ gene expression was increased (Cheong et al., 2003). In order to see if BWMK1 enhanced the resistance or not, transgenic plants and wild type plants were challenged by Phytophthora parasitica pathogen (Cheong et al., 2003). Transgenic plants were healthy after 8 days; however, the wild type plants showed disease symptoms (Cheong et al., 2003). In tobacco, two MAPKs, SIPK and WIPK, can be activated by abiotic signals and pathogen-related signals (Cheong et al., 2003) and the activation is probably mediated by NtMEK2, an upstream MAPKK (Cheong et al., 2003). Activation of NtMEK2 can cause hypersensitive cell death and the expression of defense genes (Yang et al., 2001; Zhang and Liu, 2001); therefore, SIPK and WIPK are important for defense (Cheong et al., 2003). 


\subsection{Wheat (Triticum aestivum) project}

The model used in this study is wheat (Triticum aestivum). A few MAPKs have been identified in wheat and other monocot species such as rice and maize (Yang and Xiong, 2008). Wheat is one of the most significant food crops in the world representing a stable food supply for $35 \%$ of the world's population (Niu et al., 2005). One of the major factors that affect wheat growth and development is disease.

The fungus Puccinia triticina causes wheat leaf rust, a common disease that has been a worldwide problem that resulted in a wheat yield loss of up to $15 \%$ (Kolmer, 1996). The wheat leaf rust disease is a good example to use to study the fungal disease of plants (Jordan et al.,2006). A common model to study the pathogen-plant interactions is the gene-for-gene model, which works when a pathogen $A v r$ gene product interacts with a host $R$ gene product (Flor, 1971). At the site of the infection, the presence of single leaf rust resistance genes in near-isogenic lines confer resistance to avirulent races, which results in a hypersensitive response with localized cell death (Kolmer, 1996; Jordon et al., 2006). Another fungal pathogen is Fusarium graminearum that causes Fusarium head blight (FHB) in wheat (Gilbert and Tekauz, 2000). Associated mycotoxins such as deoxynivalenol (DON), moniliformi and zearalenon cause the problem of grain contamination, which is the most serious threat of FHB (Yang et al., 2006).

Many defense responses in plants depend on recognizing the pathogen via gene-forgene interactions. $R$ genes may consist of a leucine-rich repeat (LRRs) and a nucleotide binding domain (NB). The NB-LRR $R$ genes are divided into subfamilies that contain (CC-NB-LRR), a 
coiled coil structure, or TIR-NB-LRR, a Drosophila Toll and Human interleukin 1 receptor (Xing, 2007). The $\mathrm{R}$ gene product detects the presence of pathogen avirulence (Avr) factor and initiates downstream signaling responses (Xing, 2007).

The activated defense pathways also include the MAPK cascades. Protein kinases are important for plants to defend against pathogens by evoking the transcription of different genes and regulating the activity of downstream proteins (Xing et al., 2008). The defense responses may appear in the form of systemic acquired resistance (SAR), redox status change, the activation of pathogenesis-related $(P R)$ genes, and hypersensitive response (HR)-like cell death (Xing et al., 2008). The receptor-like kinase XA21 is needed for resistance to the Xanthomonas oryzae bacterial pathogen in rice. The effector AvrPto from Pseudomonas Syringae can be recognized by Pto, a Ser/Thr protein kinase in tomato (Tang et al., 1996; Kim et al., 2002).

A common fungus Fusarium verticillioides produces a toxin named fumonisin B1 (FB1) (Asia et al., 2000). This fungal toxin acts as a ceramide synthase competitive inhibitor to disrupt sphingolipid metabolism in eukaryotes (Desai et al., 2002). Ceramid synthase is a key enzyme in sphingolipid biosynthesis (Stone et al., 2000). Sphingolipid acts as a secondary messenger regulating growth, differentiation and apoptosis (Stone et al., 2000), and as an anchor for membrane proteins (Futerman, 1995). Numerous stress-activated protein kinases and phosphatases are activated by the sphingolipid ceramide (Nickels and Broach, 1996; Stone et al., 2000). In Arabidopsis protoplasts, cell death signaling was induced by FB1 (Asai et al., 2000).

For my thesis, the following work will be presented: (1) microscopic study of cell death in Frontana (FHB resistant) and Roblin (FHB susceptible) wheat cultivars under salicylic acid (SA) and Fumonisin B1 (FB1) treatments; (2) DNA ladders in Frontana and Roblin under SA 
and FB1 treatments; (3) regulation of DNA repairing genes including RAD50, RAD51, and MSH2; (4) analysis of enzyme activities including $\beta$-1, 3-glucanase, and glutamine synthetase; (5) the analysis of gene expression levels of FLR under SA and FB1 treatments. The plan is shown in Figure 1-2. 


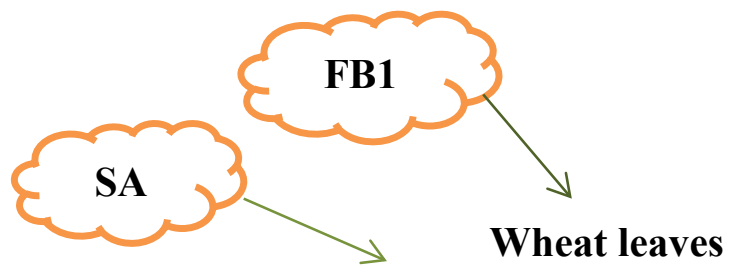

(Frontana and Roblin)

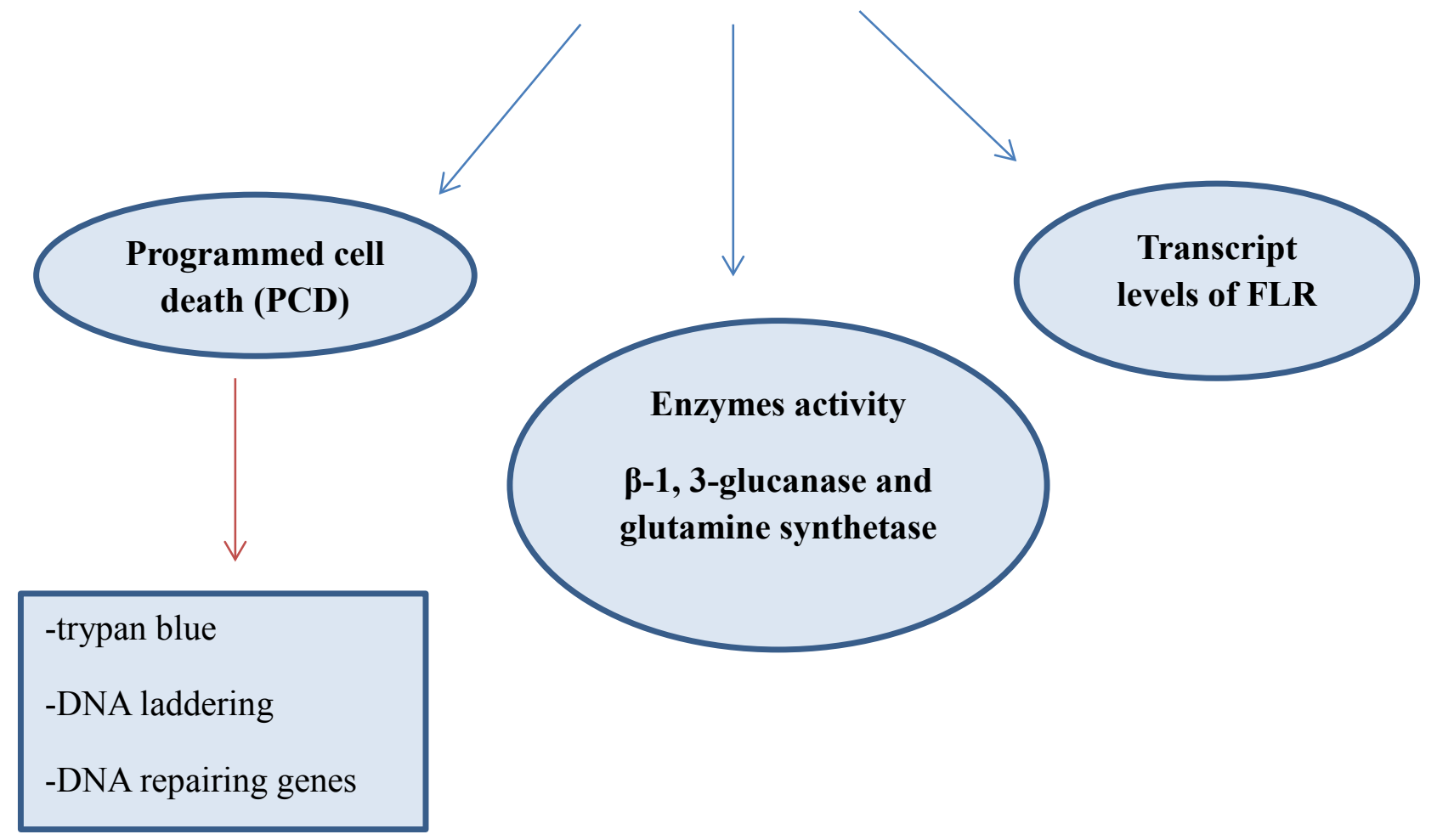

Figure 1-2: Overview of my project on wheat defense pathways. Green arrows indicate that wheat leaves will be treated by SA and FB1. Blue arrows indicate that programmed cell death, PR enzyme activity, and FLR transcript levels will be examined. Red arrow indicates the methods and RT-PCR for repairing genes that are used to show PCD. 


\section{Chapter II}

\section{Methods and Materials}

\subsection{Plant materials and growth conditions}

Wheat seeds (Roblin and Frontana) were kindly provided by Dr. Therese Ouellet in Agriculture and Agri-Food Canada. To begin with, $70 \%$ ethanol was used to sterilize the seeds for 2 minutes and the seeds were then transferred to another sterilization solution $(25 \%$ Bleach $\mathrm{v} / \mathrm{v}$ and $0.01 \%$ Triton $\mathrm{X}-100 \mathrm{v} / \mathrm{v})$ for 8 minutes. Then, the seeds were washed with distilled water 10 times. Seeds were planted in autoclaved soil Pro-mix BX (Ritchie Feed \& Seed Inc. Ottawa, Ontario). Each pot of wheat was fertilized with 7-9 $\mathrm{mL}$ granular 14:14:14 slow release fertilizer. Wheat seeds were grown in growth chambers (ENCONAIR Technologies Inc, Winnipeg, Manitoba) in $16 \mathrm{hr}$ of light at $17^{\circ} \mathrm{C}$ and $8 \mathrm{hr}$ of dark at $15^{\circ} \mathrm{C}$.

\subsection{SA and FB1 treatment}

Leaves of three-week-old Roblin and Frontana leaves were collected, cut into $\sim 2 \mathrm{~cm}$ segments, infiltrated in $5 \mu \mathrm{M}$ FB1 or $100 \mu \mathrm{M}$ SA (Segma). Then, in Petri dishes, the leaf segments were covered by the solution by placing them upward on filter papers. An equal volume of distilled water was used as a control treatment. Leaf segments were collected after $24 \mathrm{hr}$ and $48 \mathrm{hr}$ incubation. Liquid nitrogen was used to freeze the leaves after collecting them in falcon tubes. They were stored at $-80^{\circ} \mathrm{C}$ and used for RNA extraction within 3 months. 


\subsection{Programmed cell death}

\subsubsection{Trypan blue staining}

An Axioplan 2 microscope was used to photograph the cells of the wheat leaves (Carl Zeiss, Germany). Methods described by Tang et al. (1999) and Stone et al. (2000) were used with minor adjustments for detection of cell death. To begin with, wheat leaves were placed in $10 \mathrm{~mL}$ of ethanol-lactophenol (2 volumes of ethanol and 1 volume of phenol-glycerol-lactic acid-water $(1: 1: 1: 1))$ that contained $0.05 \%$ trypan blue. The samples were incubated for 4

minutes at $95^{\circ} \mathrm{C}$, and were then kept for $20 \mathrm{~min}$ at room temperature. Following this, $1.5 \mathrm{~mL}$ chloral hydrate destaining solution $(2.5 \mathrm{~g} / \mathrm{mL}$ of nano pure water) was added to each tube after removing the staining solution. For 2 days, the destaining solution was replaced twice to clear the leaves. After destaining, the leaves were suspended in $50 \%$ glycerol and put on microscope slides, and they were examined with white light under Axioplan 2 microscope (Carl Zeiss, Germany).

\subsubsection{DNA laddering analysis}

DNA was extracted from wheat leaves using the TRIzol Reagent kit (Invitrogen, USA). A volume of $1 \mathrm{~mL}$ of TRIzol was added to the leaf tissue $(100 \mathrm{mg})$ followed by immediate homogenization. After homogenization, the samples were incubated at room temperature for 5 min to permit the complete dissociation of nucleoprotein complexes. Then, $200 \mu \mathrm{L}$ of chloroform was added and the samples were shaken by hand for 15 seconds and then incubated at room temperature for 2-3 min. The samples were centrifuged at $12,000 \mathrm{~g}$ at $4^{\circ}$ $\mathrm{C}$ for $15 \mathrm{~min}$. The brown aqueous bottom phase, which is DNA, was transferred into a new tube. Approximately $10 \mu \mathrm{g}$ of DNA was loaded in a $1.5 \%$ agarose gel to examine DNA 
laddering in wheat leaves treated with SA and FB1 at $0 \mathrm{hr}, 24 \mathrm{hr}$, and $48 \mathrm{hr}$ time intervals.

\subsubsection{Expression analysis of DNA repairing genes}

RNA was first extracted from wheat leaves treated with SA and FB1 (described in 2.4. RNA extraction). GAPDH gene (GenBank accession number EU022331.1) was used as an internal standard (Llyod et al., 2007). For RT-PCR, the primers were 5'GTGAGGCTGGTGCTGATTACG-3' (forward) and 5'-TGGTGCAGCTAGCATTTGAGAC-3' (reverse). The following conditions were used for RT-PCR wheat GAPDH gene: $94^{\circ} \mathrm{C}$ for 1 $\min ; 94^{\circ} \mathrm{C}$ for $1 \mathrm{~min}, 60^{\circ} \mathrm{C}$ for $1 \mathrm{~min}$, and $72^{\circ} \mathrm{C}$ for 30 seconds for 28 cycles; and then $10 \mathrm{~min}$ at $72^{\circ} \mathrm{C}$. The size of the gene was $198 \mathrm{bp}$.

RAD50 gene (GenBank accession number EU159424.1) is a DNA repairing gene. The primers for RAD50 were 5'-CAGGGACACATTGACTGGTG-3' (forward) and 5'TTTCCTCGGCAAAATGTACC-3' (reverse). The following conditions were used for RTPCR: $94^{\circ} \mathrm{C}$ for $1 \mathrm{~min} ; 94^{\circ} \mathrm{C}$ for $1 \mathrm{~min}, 67^{\circ} \mathrm{C}$ for $1 \mathrm{~min}, 72^{\circ} \mathrm{C}$ for 30 seconds for 28 cycles; and then $72^{\circ} \mathrm{C}$ for $10 \mathrm{~min}$. The size for the RAD50 gene PCR product was $176 \mathrm{bp}$.

RAD51 gene (GenBank accession number EU915557.1) is another DNA repairing gene. The primers for RAD51 were 5'-CAGAAGGCACATTCAGACCA-3' (forward) and 5'GCAAACCTTGTCTCCACCAT-3' (reverse). The RT-PCR was $94^{\circ} \mathrm{C}$ for $1 \mathrm{~min}$; $94^{\circ} \mathrm{C}$ for 1 $\min , 71^{\circ} \mathrm{C}$ for $1 \mathrm{~min}, 72^{\circ} \mathrm{C}$ for 30 second for 28 cycles; and then $72^{\circ} \mathrm{C}$ for $10 \mathrm{~min}$. The size for RAD51 gene was $166 \mathrm{bp}$.

For MSH2 gene (GenBank accession number AJ131671.1), the RT-PCR protocol was $94^{\circ}$ $\mathrm{C}$ for $1 \mathrm{~min}$; $94^{\circ} \mathrm{C}$ for $1 \mathrm{~min}, 64^{\circ} \mathrm{C}$ for $1 \mathrm{~min}, 72^{\circ} \mathrm{C}$ for 30 seconds for 28 cycles; and then $72^{\circ} \mathrm{C}$ for $10 \mathrm{~min}$. The MSH2 gene primers were 5'-AGACCAGACATCACAACATCGGAG3' (forward) and 5'-GCCATCAAGACATTTACACCAACC-3' (reverse). The size for MSH2 
gene was 206 bp.

\subsection{Expression analysis of FLR gene by RT-PCR}

RNA extraction and cDNA synthesis protocols were the same as those described in TRIzol Reagent kit (Invitrogen, USA). For RT-PCR, a wheat actin gene (GenBank accession number AB181991) with the primer sequences 5'-GCCACACTGTTCCAATCTATGA-3' and 5'-TGATGGAATTGTATGTCGCTTC-3' was used as a control. The primers for the FLR gene were 5'GGCCATTCGAGGAACATCTA-3' (forward) and 5'TTGTCGTCATTATCGGCGTA-3' (reverse). The following conditions were used for RTPCR wheat actin gene: $94^{\circ} \mathrm{C}$ for $1 \mathrm{~min} ; 94^{\circ} \mathrm{C}$ for $1 \mathrm{~min}, 61^{\circ} \mathrm{C}$ for $1 \mathrm{~min}$, and $72^{\circ} \mathrm{C}$ for 30 second for 34 cycles; and then 10 min at $72^{\circ} \mathrm{C}$. For the FLR gene, the RT-PCR protocol was $94^{\circ} \mathrm{C}$ for $1 \mathrm{~min} ; 94^{\circ} \mathrm{C}$ for $1 \mathrm{~min}, 61^{\circ} \mathrm{C}$ for $1 \mathrm{~min}, 72^{\circ} \mathrm{C}$ for seconds for 28 cycles; and then $72^{\circ} \mathrm{C}$ for $10 \mathrm{~min}$. The size for the wheat actin gene PCR product was $369 \mathrm{bp}$ and for the FLR PCR product was $218 \mathrm{bp}$.

\section{5. $\beta-1,3$ Glucanase assay}

\subsubsection{Protein extraction}

Leaf materials (Roblin $\mathrm{H}_{2} \mathrm{O} 0 \mathrm{hr}$ to $48 \mathrm{hr}$, SA $0 \mathrm{hr}$ to $48 \mathrm{hr}$, FB1 $0 \mathrm{hr}$ to $48 \mathrm{hr}$, and Frontana $\mathrm{H}_{2} \mathrm{O} 0 \mathrm{hr}$ to $48 \mathrm{hr}$, SA $0 \mathrm{hr}$ to $48 \mathrm{hr}$, FB1 $0 \mathrm{hr}$ to $48 \mathrm{hr}$ ) were homogenized in 0.05 mol/L sodium acetate buffer ( $\mathrm{pH} 5.2$ ) containing sodium acetic acid $\mathrm{pH} 5.19$, DLdithiothreitol (DTT) $5 \mathrm{mM}$, and PMSF $1 \mathrm{mM}$, using a pestle and mortar at $4^{\circ} \mathrm{C}$. Then, the samples were centrifuged at $12,000 \mathrm{~g}$ for $20 \mathrm{~min}$ at $4^{\circ} \mathrm{C}$. The clear phase was used as a crude extract. 


\subsubsection{Bio-Rad protein assay}

First, $50 \mathrm{~mL}$ of the dye reagent was prepared by mixing $10 \mathrm{~mL}$ of the dye reagent (BioRad, USA) with 40mL distilled de-ionized water. Secondly, protein standard dilutions were prepared ranging from $0.05 \mathrm{mg} / \mathrm{mL}$ to $0.50 \mathrm{mg} / \mathrm{mL}$. Then, into separate microtiter plate wells, $10 \mu \mathrm{L}$ of each standard and each sample were loaded. To each well, $200 \mu \mathrm{L}$ of the diluted dye reagent was added. The samples and the dye reagent were then mixed, and then they were incubated for $5 \mathrm{~min}$ at room temperature. The absorbance was measured at $595 \mathrm{~nm}$ using Epoch Microplate Spectrophotometer (BioTek Instruments, USA). Following this, a BSA standard curve was plotted using the absorbance at 595nm against the concentration of the protein standard dilutions $(\mathrm{mg} / \mathrm{mL})$. Therefore, the concentration of the protein samples was determined using the BSA standard curve.

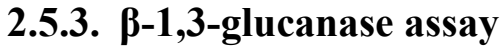

$\beta$-1,3-glucanase assay activity was determined according to the rate of reducing-sugar production with laminarin. The reaction mixture consisted of $0.4 \mathrm{~mL}$ of McIIvaine's citric acid-phosphate buffer ( $\mathrm{pH}$ 5.6) containing $1 \mathrm{mg} / \mathrm{mL}$ laminarian and $0.1 \mathrm{~mL}$ of enzyme solution. The reaction mixture was then incubated at $37^{\circ} \mathrm{C}$ for $15 \mathrm{~min}$. The mixtures were immediately heated for $10 \mathrm{~min}$ at $100^{\circ} \mathrm{C}$ after adding $0.5 \mathrm{~mL}$ of the alkaline copper reagent. The samples were then cooled on ice, and $0.5 \mathrm{~mL}$ of the arsenomolybdate reagent was then added. After the development of a blue color, $3.0 \mathrm{~mL}$ of double distilled water was added. The absorbance was measured at $660 \mathrm{~nm}$ using Epoch ${ }^{\mathrm{TM}}$ Multi-Volume Spectrophotometer System. 


\subsection{Glutamine synthetase assays}

Fresh wheat leaves or frozen leaves were homogenized in $0.05 \mathrm{M}$ sodium acetate buffer (pH 52) containing sodium acetic acid $(\mathrm{pH} 5.19)$, DTT 5mM, and PMSF 1mM, using a pestle and mortar at $4^{\circ} \mathrm{C}$. The samples were then centrifuged at $12,000 \mathrm{~g}$ for $30 \mathrm{~min}$ at $4^{\circ} \mathrm{C}$. The clear phase was used as a crude extract. Following this, $100 \mu \mathrm{L}$ of leaf extract was transferred to a tube and $380 \mu \mathrm{L}$ of assay mix was added to it. This assay mix consists of 100 $\mathrm{mM}$ Triethanolamine (TEA), $80 \mathrm{mM}$ glutamate, $6 \mathrm{mM}$ hydroxylamine $\mathrm{HCl}, 20 \mathrm{mM} \mathrm{MgSO}$, and $4 \mathrm{mM}$ EDTA at $\mathrm{pH}$ 7.6. To start the reaction, $20 \mu \mathrm{L}$ of $0.2 \mathrm{M} \mathrm{ATP}$ at $\mathrm{pH} 7.6$ was added. The reaction was incubated for $10 \mathrm{~min}$ at $30^{\circ} \mathrm{C}$. Then, $500 \mu \mathrm{L}$ of ferric chloride reagent containing $0.24 \mathrm{M}$ Trichloroacetic acid (TCA), $0.1 \mathrm{M}$ ferric chloride, $1.0 \mathrm{M} \mathrm{HCl}$, was added to stop the reaction. Finally, the samples were centrifuged for $5 \mathrm{~min}$ at $10,000 \mathrm{~g}$, and the absorbance was read at $505 \mathrm{~nm}$. 


\section{CHAPTER III}

\section{RESULTS}

\subsection{Introduction}

Plants are under the threat of biotic and abiotic stresses. One type of response to these stresses is programmed cell death (PCD) (Beers and McDowell, 2001). During pathogen attack, cell death occurs in susceptible and resistant plants (Pozo et al., 2004).

Cell death is a characteristic of immune responses in both plants and animals. Pathogens can penetrate the multiple layers of host defense causing disease development, activating the immune system to minimize the damage. They respond to the infection of pathogens by programmed cell death (Coll et al., 2011).

Most of the information about PCD was obtained using the cell culture system (Ning et al., 2002). One of the common characteristics of PCD is DNA ladder in animals and plants. The DNA ladder characteristic is described as DNA fragmentation that occurs during cell death while cell structures including lysosomes and vacuoles are conserved (Danon et al., 2000).

In reproducing organisms, recombination and DNA repair are necessary processes that occur during meiosis. Genes that have been identified in bread wheat (Tritium aestivum) that may have a role in the control of these processes include RAD50, RAD51, and MSH2 (Lloyd et al., 2007).

RAD50 (GenBank accession number EU159424.1) is involved in DNA damage repairing, DNA replication, meiosis, and telomere maintenance (Czornak et al., 2008; Lamarch et al., 2010). RAD51 was discovered in Saccharomyces cerevisiae (Bishop et al., 1992) and is 
responsible for DNA strand exchange (Shinohara et al., 1992). Wheat RAD50 (GenBank accession number EU915557.1) is involved in meiosis (Khoo et al., 2008).

In this work, a pathogenesis-related enzyme and a growth-related enzyme were also studied. Pathogen recognition and downstream responses have been the focus of many studies. However, an intriguing, but understudied, phenomenon is how plants are able to recruit energy or reduce nutrient loss during the defense response. Recognition of pathogens results in a massive reprogramming of the plant cell to activate and deploy defense responses to halt pathogen growth. Such responses are associated with increased demands for energy, reducing equivalents, and carbon skeletons that are provided by primary metabolic pathways (Bolton, 2009; Fan et al., 2009).

The enzymes $\beta$-1, 3-glucanase and glutamine synthetase (GS) were selected. A fungal cell wall is composed of polysaccharides, $\beta$-glucans, chitin, and mannans. The structure of the fungal cell wall is a branched $\beta$-1, 3-glucan cross-linked to chitin. In plant-fungus interactions, fungal specific molecules such as cell membrane sterols and cell wall polysaccharides can be recognized by the plants as pathogen associated molecular patterns (PAMPs) through pattern recognition receptors (PRRs) (Fujikawa et al., 2012). During plant defense response, $\beta$-1, 3-glucan linker in fungal cell wall is hydrolyzed by the induced plant $\beta$-1, 3-glucanase. Overexpressing $\beta$-1, 3-glucanase gene increased resistance against fungal pathogens (Liu et al., 2009).

In addition, during plant growth and development, nitrogen can be assimilated with the action of glutamine synthetase, forming glutamine. Transgenic approach has been applied in the attempt to enhance GS activity and to improve nitrogen assimilation (Man et al., 2011; 
Seabra et al., 2010). Ectopic expression of bacterial glutamine dehydrogenate in transgenic tobacco and corn was the main focus in order to enhance nitrogen utilization (Mungur et al., 2005), resulting in the ammonium incorporation into glutamine (Man et al., 2011). The intermediate products of this pathway are a source of some purine bases used for nucleic acid biosynthesis, the synthesis of a number of essential coenzymes, and for the biosynthesis of signaling molecules (Man et al., 2011).

SA signaling plays a role in the defense response and it leads to PR gene induction and systemic acquired resistance (SAR) (Delaney et al., 1994; Morris et al., 2000). Fusarium verticillioides produces FB1 (Asai et al., 2000) and it was used as a biotic stressor in this project. To determine whether FLR may play a role in response to the biotic stressor FB1, the transcriptional level of FLR was tested by RT-PCR upon SA and FB1 treatment.

\subsection{SA and FB1 induced cell death in Frontana and Roblin}

Leaves from three-week old Frontana and Roblin were used. The leaves were treated with water, $100 \mu \mathrm{M} \mathrm{SA}$, or $5 \mu \mathrm{M} \mathrm{FB1}$, for up to $72 \mathrm{hr}$. Trypan blue was used to stain the dead cells. Under the light, dead cells appeared to be dark blue, and cell death did not occur in whole leaves. Microscopic images were used to show the death sites. By focusing on one of several representative leaf areas, the pictures were taken from leaves that were treated with water, SA or FB1 for $0 \mathrm{hr}, 24 \mathrm{hr}$, and $48 \mathrm{hr}$. It seems that cell death occurred on the leaf vein in all of the treatments (Figure 3-1-a-b-c); however, it occurred outside of the vein only when the leaves were treated with FB1 for $24 \mathrm{hr}$ and $48 \mathrm{hr}$ (Figure 3-1-f). Cell death first appeared in both Roblin and Frontana leaves that were treated with $24 \mathrm{hr}$ FB 1 . Cell death did not occur in leaves treated with water. Meanwhile, SA did not affect Roblin, but in Frontana there was an SA effect. Microscopic data are shown in Figure 3-1 and 3-2. 
Figure 3-1: Light Microscopy images of Frontana and Roblin leaves. All plants were grown in a growth chamber (16hr light/8hr dark). After three weeks, leaves were treated with water, $100 \mu \mathrm{M}$ SA and $5 \mu \mathrm{M}$ FB1 treatment. Trypan blue was used on the treated leaves. A white light by Axioplan 2 microscope was used for microscope images of the treated leaves. Two experiments were carried out with similar results.

a. Cell death of Frontana and Roblin leaf veins under water (control) treatment by trypan blue assay.

b. Cell death of Frontana and Roblin leaf veins under $100 \mu \mathrm{M}$ SA treatment by trypan blue assay.

c. Cell death of Frontana and Roblin leaf veins under $5 \mu \mathrm{M}$ FB1 treatment by trypan blue assay.

d. Cell death outside of Frontana and Roblin leaf veins under water (control) treatment by trypan blue assay.

e. Cell death outside of Frontana and Roblin leaf veins under $100 \mu \mathrm{M}$ SA treatment by trypan blue assay.

f. Cell death outside of Frontana and Roblin leaf veins under $5 \mu \mathrm{M}$ FB1 treatment by trypan blue assay. 
a) Water (control), in leaf vein

Frontana(resistance)

$\mathrm{H}_{2} \mathrm{O} 0 \mathrm{hr}$

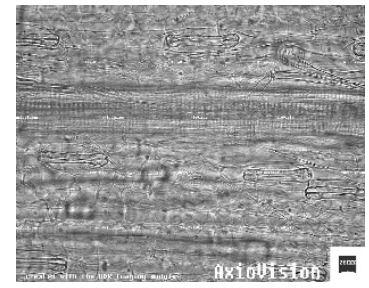

$\mathrm{H}_{2} \mathrm{O} 24 \mathrm{hr}$

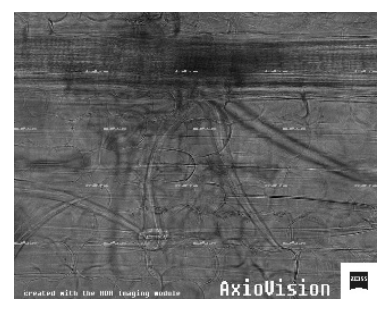

$\mathrm{H}_{2} \mathrm{O} 48 \mathrm{hr}$

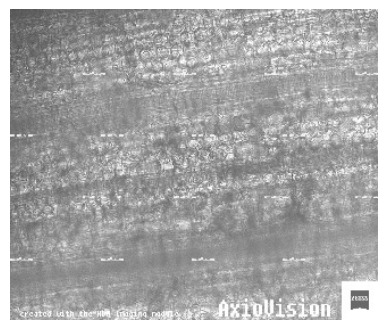

Roblin(susceptible)
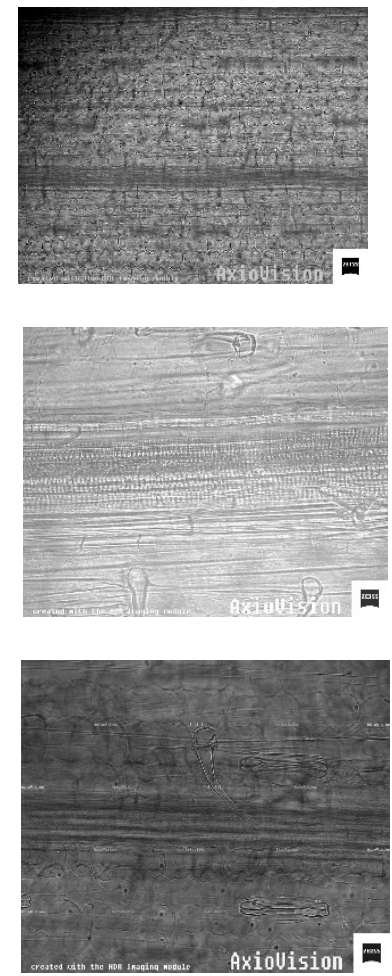
b) $100 \mu \mathrm{M} \mathrm{SA}$ treatment, in leaf veins

Frontana(resistance)

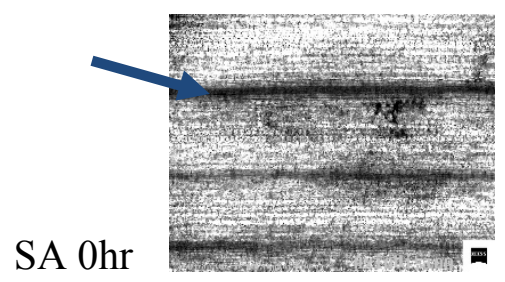

SA $24 \mathrm{hr}$

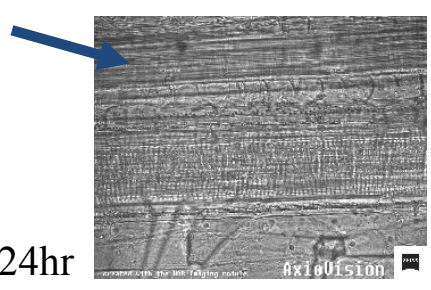

SA $48 \mathrm{hr}$
Roblin(susceptible)
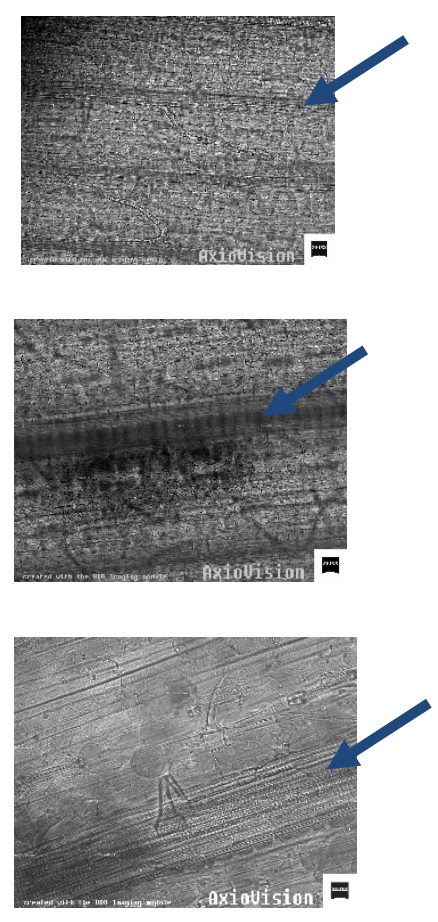


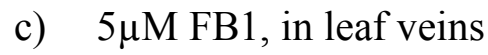

Frontana(resistance)

FB1 0hr

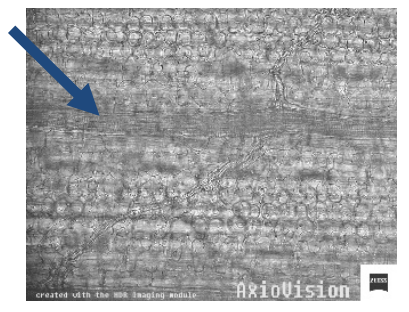

FB1 24hr

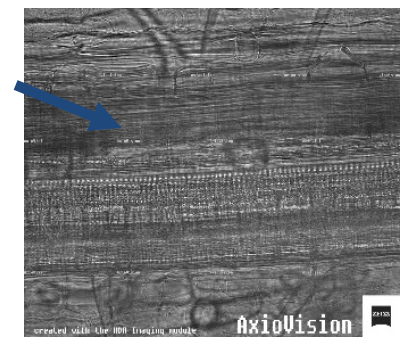

FB1 48hr
Roblin(susceptible)
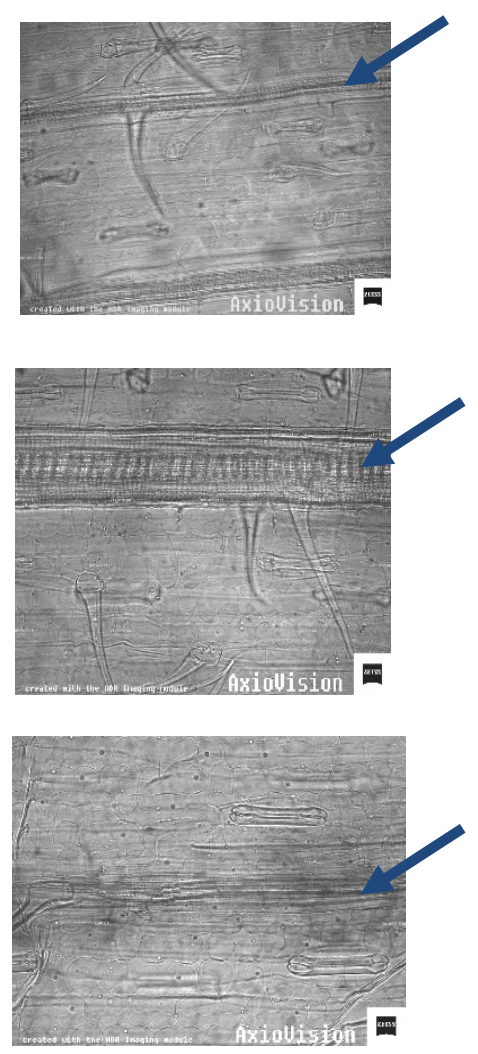
d) Water (control), outside leaf veins

Frontana(resistance)

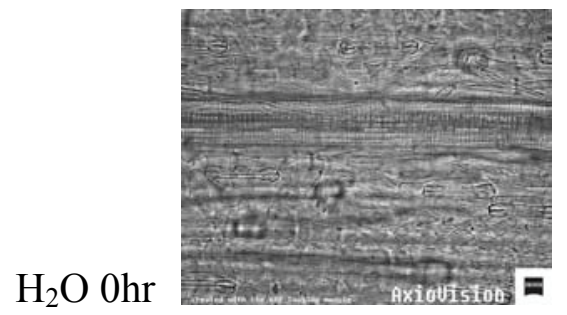

$\mathrm{H}_{2} \mathrm{O} 24 \mathrm{hr}$

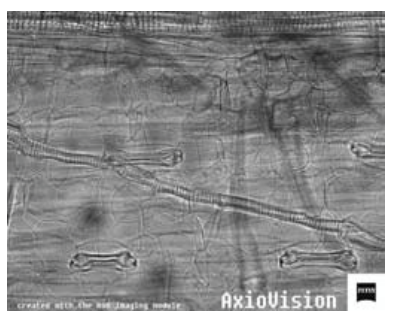

$\mathrm{H}_{2} \mathrm{O} 48 \mathrm{hr}$

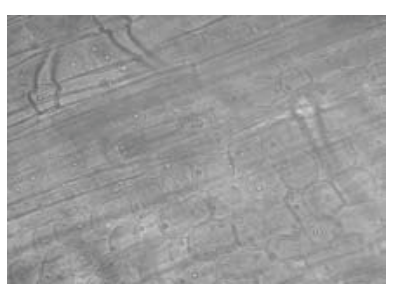

$\mathrm{H}_{2} \mathrm{O} 72 \mathrm{hr}$
Roblin(susceptible)
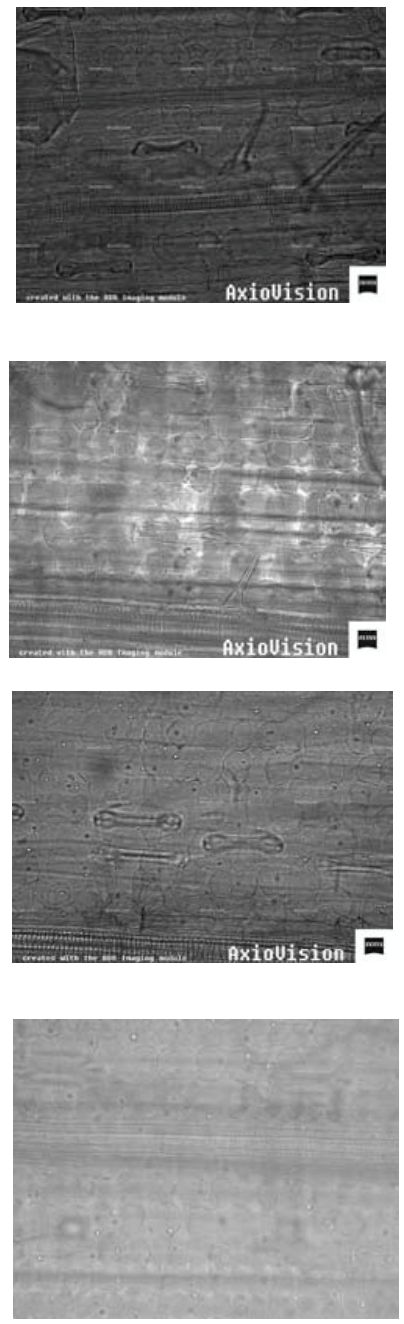
e) $100 \mu \mathrm{M} \mathrm{SA}$ treatment, outside leaf veins

Frontana(resistance)
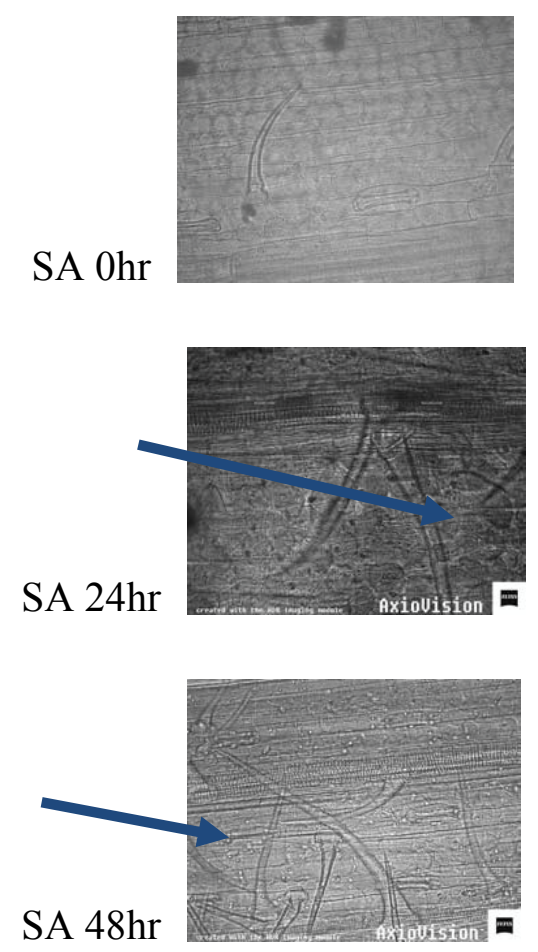

SA $72 \mathrm{hr}$

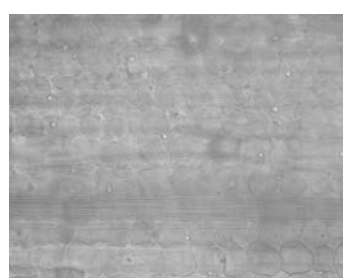

Roblin(susceptible)
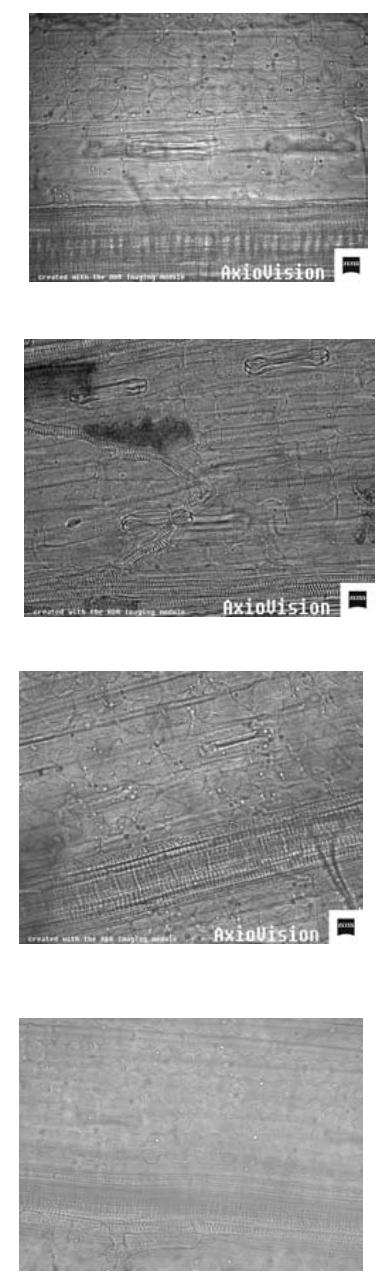
f) $5 \mu \mathrm{M}$ FB1, outside leaf veins

Frontana(resistance)

FB1 0hr

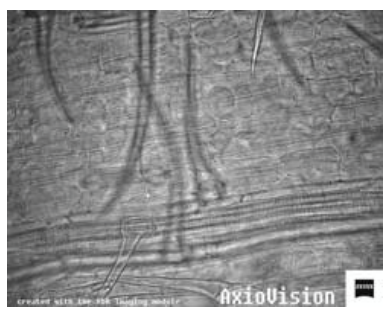

FB1 24hr

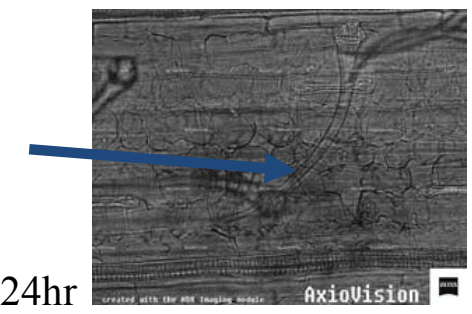

FB1 48hr

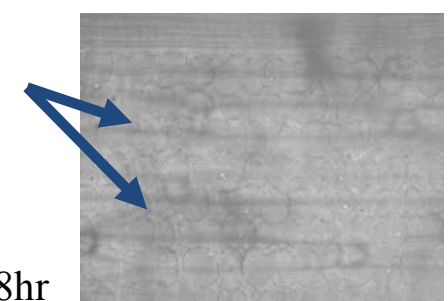

FB172hr

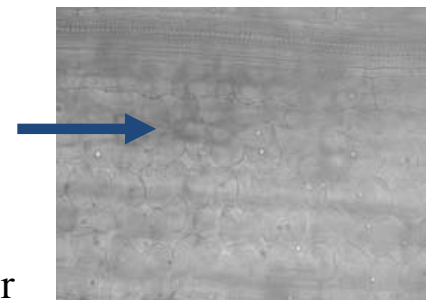

Roblin(susceptible)
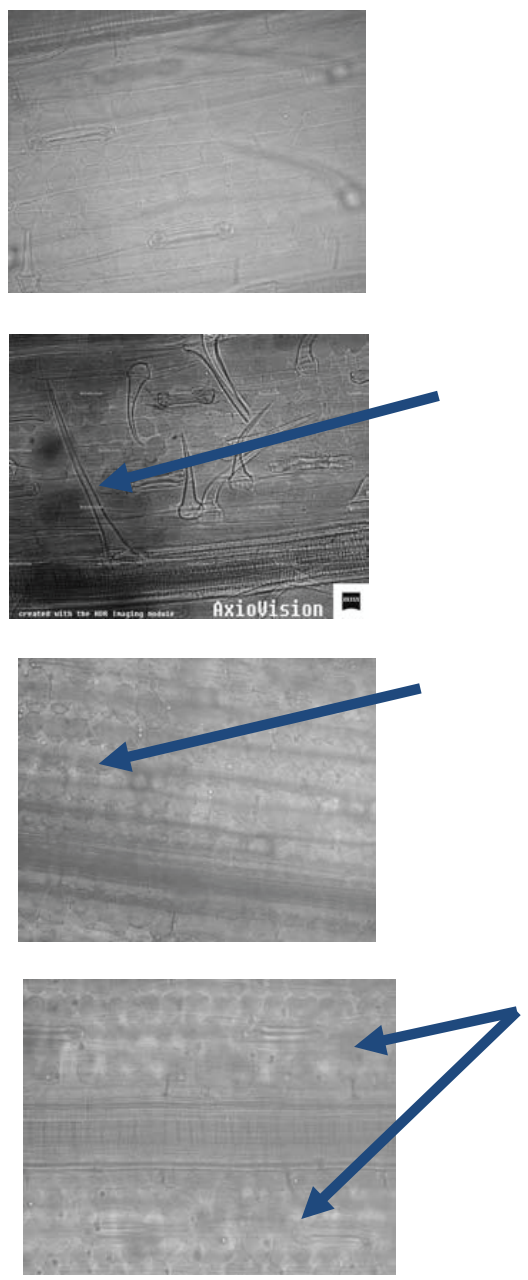
Figure 3-2: Images of Frontana and Roblin leaves with SA and FB1 treatment. Plants were grown in a growth chamber (16hr light/8hr dark). Three-week old leaves were treated with $100 \mu \mathrm{M}$ SA and $5 \mu \mathrm{M}$ FB1. Images were captured by a digital camera. Two experiments were carried out.

a) Frontana and Roblin leaves treated with $100 \mu \mathrm{M}$ SA.

b) Frontana and Roblin leaves treated with $5 \mu \mathrm{M}$ FB1. 
a) $100 \mu \mathrm{M} \mathrm{SA}$

Frontana

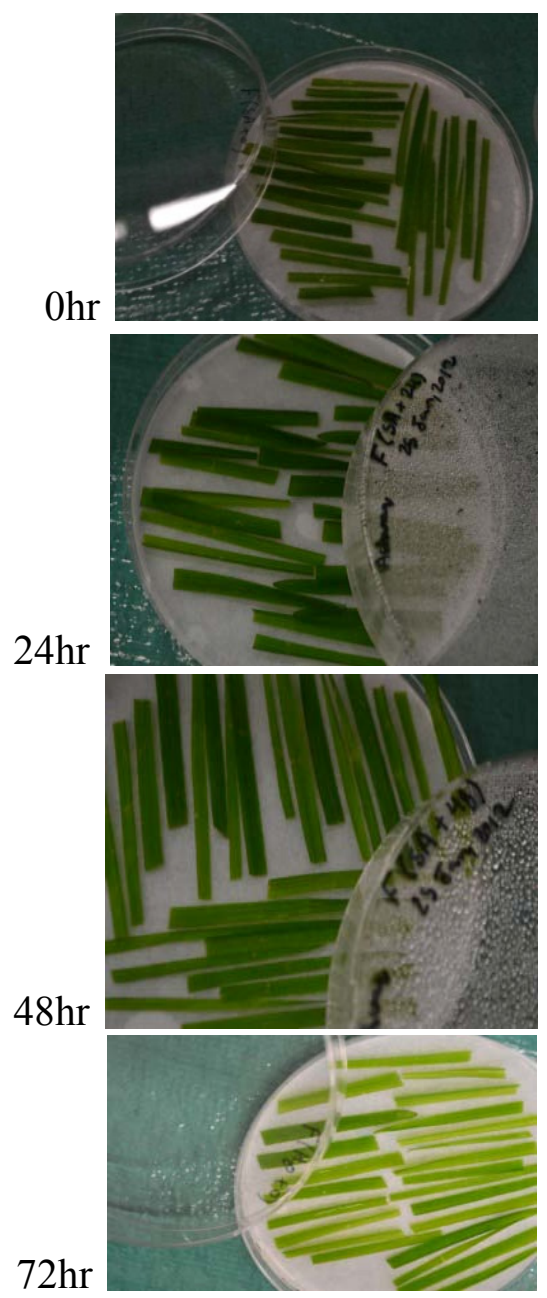

Roblin
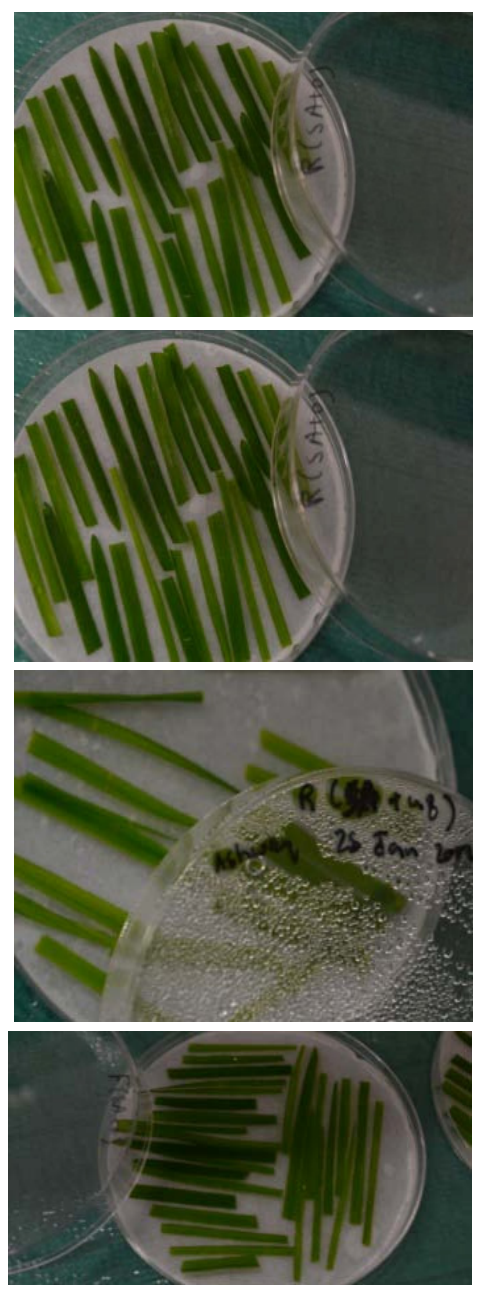
b) $5 \mu \mathrm{MFB} 1$

Frontana

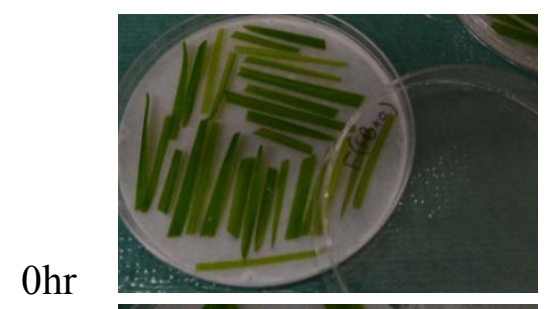

$24 \mathrm{hr}$

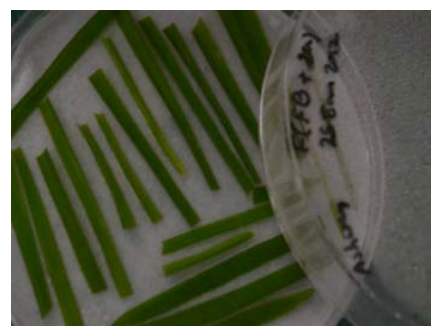

$48 \mathrm{hr}$

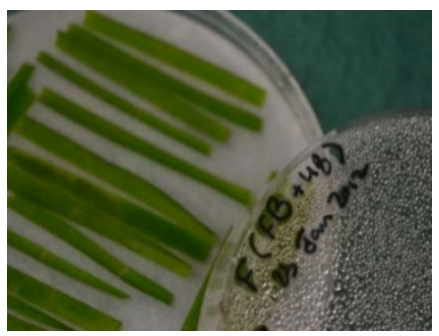

Roblin
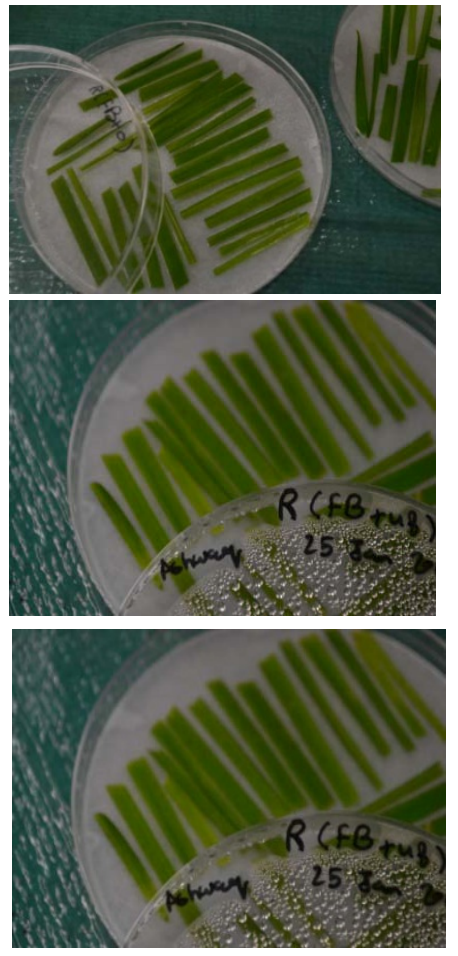
Table 3-1: The comparison of cell death measured using trypan blue in Roblin and Frontana under SA and FB1 treatments

\begin{tabular}{|c|c|c|}
\hline Hours-treatment & Roblin & Frontana \\
\hline Water $0 \mathrm{hr}$ & No cell death & No cell death \\
\hline Water $24 \mathrm{hr}$ & Cell death & No cell death \\
\hline Water $48 \mathrm{hr}$ & Cell death & Cell death \\
\hline Water $72 \mathrm{hr}$ & Cell death & Cell death \\
\hline SA $0 \mathrm{hr}$ & No cell death & No cell death \\
\hline SA $24 \mathrm{hr}$ & No cell death & Cell death \\
\hline SA $48 \mathrm{hr}$ & No cell death & Cell death \\
\hline SA $72 \mathrm{hr}$ & No cell death & No cell death \\
\hline FB $0 \mathrm{hr}$ & No cell death & No cell death \\
\hline FB $24 \mathrm{hr}$ & Cell death & Cell death \\
\hline FB $48 \mathrm{hr}$ & Cell death & Cell death \\
\hline FB $72 \mathrm{hr}$ & Cell death & Less Cell death \\
\hline
\end{tabular}


Plants have many defense mechanisms in response to pathogen attacks. Programmed cell death is one of those defense mechanisms. Fumonisin B1, a PCD-eliciting fungal toxin, has been shown to trigger dosage-dependent cell death in Arabidopsis (Asai et al., 2000). In our work, it was shown that FB1 induced cell death in Frontana (a resistant cultivar) and Roblin (a susceptible cultivar). It has been suggested that the activation of cell death is necessary in some host-pathogen interactions, while in others cell death is not essential for disease resistance (Lam et al., 2001). 


\subsection{SA and FB1 treatment and DNA ladders in Roblin and Frontana}

It is valuable to understand PCD at the tissue level (such as leaves) or the whole plant level. One of the most common characteristics of PCD in animals and plants is the DNA ladder. The DNA ladder refers to DNA fragmentation during part of the cell death process while cell structures such as vacuoles or lysosomes are preserved (Xing et al., 2005). Our previous work has indicated that DNA laddering occurred in wheat leaf cells when they were stressed by heat shock (Fan and Xing, 2004).

Using agarose gel electrophoresis, we tried to examine the integrity of DNA in wheat leaves after biotic stress treatment. Fresh Roblin and Frontana leaves were treated with $100 \mu \mathrm{M}$ $\mathrm{SA}$ and $5 \mu \mathrm{M}$ FB1 for different periods of time $(0 \mathrm{hr}, 24 \mathrm{hr}$, and $48 \mathrm{hr})$. DNA was isolated from untreated leaves and treated leaves. As shown in Figure 3-3, there was no DNA laddering or smearing in treated Roblin and Frontana leaves. 
Figure 3-3: Wheat leaf DNA smearing after SA and FB1 treatments.

a) Roblin leaves DNA laddering and smearing after SA and FB1 treatments.

b) Frontana leaves DNA laddering and smearing after SA and FB1 treatments.

The gel lane setting is:

1- Water, $0 \mathrm{hr}$

2- $\quad$ Water, $24 \mathrm{hr}$

3- Water, $48 \mathrm{hr}$

4- $\quad \mathrm{SA}, 0 \mathrm{hr}$

5- $\quad$ SA, $24 \mathrm{hr}$

6- $\quad \mathrm{SA}, 48 \mathrm{hr}$

7- $\quad$ FB1, $0 \mathrm{hr}$

8- FB1, 24hr

9- $\quad \mathrm{FB} 1,48 \mathrm{hr}$ 
a) Roblin

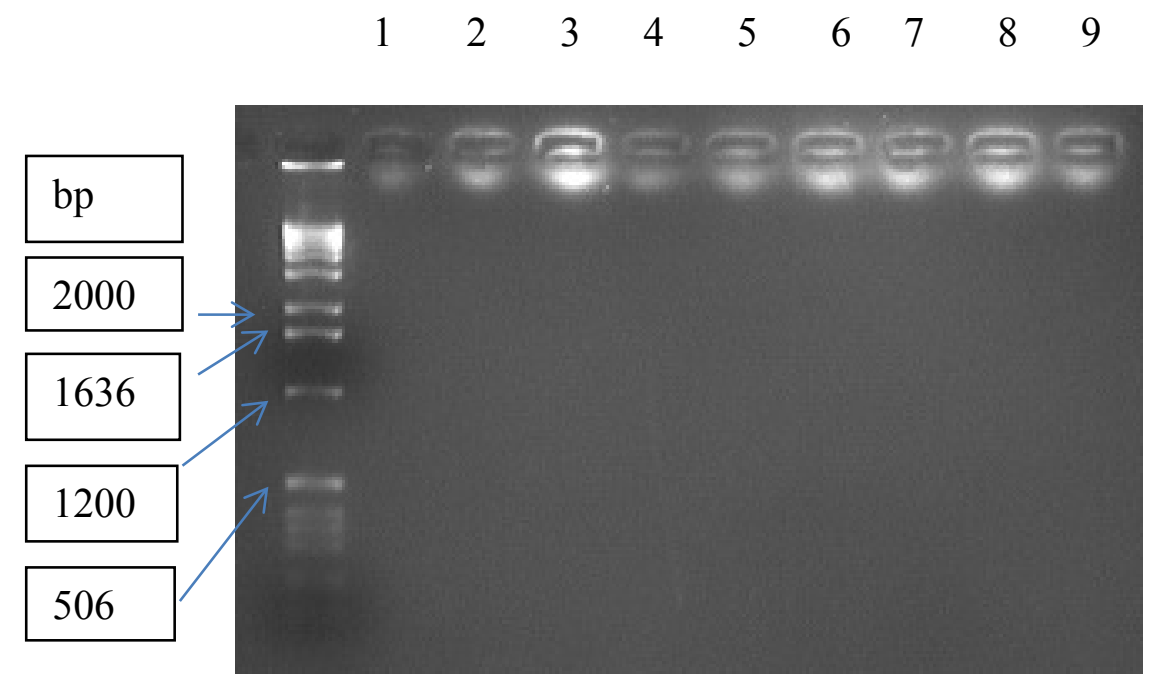


b) Frontana

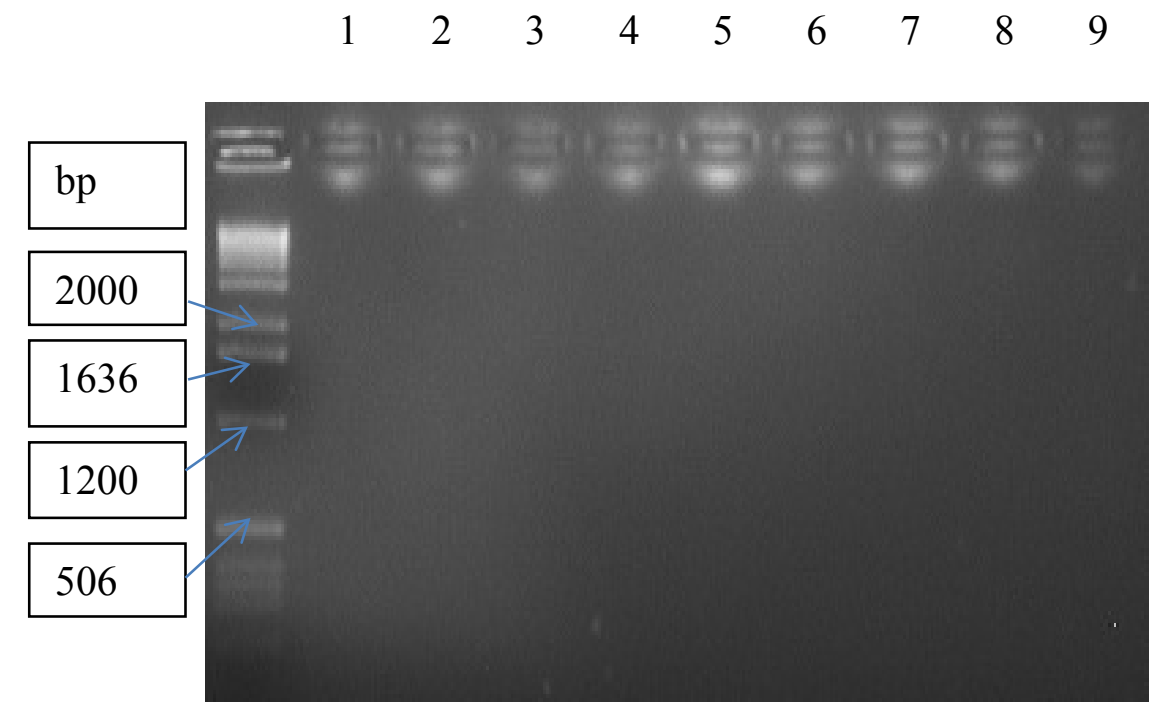




\subsection{Expression of DNA repairing genes in wheat leaves treated with SA and FB1}

\subsubsection{Radiation sensitive 50 (RAD 50) and RAD 51}

DNA repairing genes including RAD50 and RAD51 have been identified in yeast, animals and plants and they are involved in various processes such as DNA damage repairing, DNA replication, meiosis, and telomere maintenance (Lloyd et al., 2007; Czornak et al., 2008; Lamarch et al., 2010). In order to examine whether RAD50 and RAD51 (GenBank accession number EU159424.1 and EU915557.1, respectively, Table 3-2 ) are involved in DNA damage repairing in the case of a pathogen attack or a defense response, the DNA integrity of threeweek old wheat leaves from Roblin and Frontana treated with water, $100 \mu \mathrm{M}$ SA, and $5 \mu \mathrm{M}$ FB1

for $0 \mathrm{hr}, 24 \mathrm{hr}$, and $48 \mathrm{hr}$ was examined. The size of the RT-PCR products was 179bp for RAD50 and 166bp for RAD51. There was no significant change in the expression levels of either RAD50 or RAD51 in Roblin. However, there was an increase in the transcript levels of RAD50 and RAD51 at the 24hr time interval after the FB1 treatment in Frontana (Figure 3-4). It seems possible that the DNA repairing mechanism may help reduce the damage in Frontana during a fungal toxin treatment.

\subsubsection{MSH2 mismatch repairing gene expression}

Mismatch repair (MMR) genes play a key role in DNA integrity maintenance by correcting DNA mismatches that arise during DNA replication and antagonizing genetic recombination between diverged sequences (Bray and West, 2005; Iyer et al., 2006; Lloyd et al., 2007). To examine whether there is a difference between Roblin and Frontana in their DNA mismatch repairing mechanism, we studied the expression of MSH2 gene after treatment. 
Three-week old wheat leaves were treated with water, $100 \mu \mathrm{M} \mathrm{SA}$, and $5 \mu \mathrm{M}$ FB1 for $0 \mathrm{hr}$, $24 \mathrm{hr}$, and $48 \mathrm{hr}$. According to the PCR primers adopted from Lloyd et al., 2007, the size for MSH2 is 206bp. It was noticed that MSH2 gene expression was not altered with all the treatments in both cultivars (Figure 3-4). As enzyme MSH2 forms heterodimers with other MMR proteins during the repairing process and many MSH genes are involved, it is reasonable to assume that its expression may not necessarily be altered (Li, 2008; Lloyd et al., 2007). 
Figure 3-4: DNA repairing genes expression on wheat leaves treated with SA and FB1. Leaf RNA was extracted from three week old plants (Roblin and Frontana) treated with water, SA, and FB1 for 0hr, 24hr, and 48hr. GAPDH gene (GenBank accession number EU022331.1) was used as an internal standard (Jin and Bian, 2004). Five experiments were carried out with similar results.

a) RAD50, RAD51, MSH2, and GAPDH gene expression in wheat leaves treated with water (control).

b) RAD50, RAD51, MSH2, and GAPDH gene expression in DNA repairing in wheat leaves treated with SA.

c) RAD50, RAD51, MSH2, and GAPDH gene expression in DNA repairing on wheat leaves treated with FB1. 

a) Water

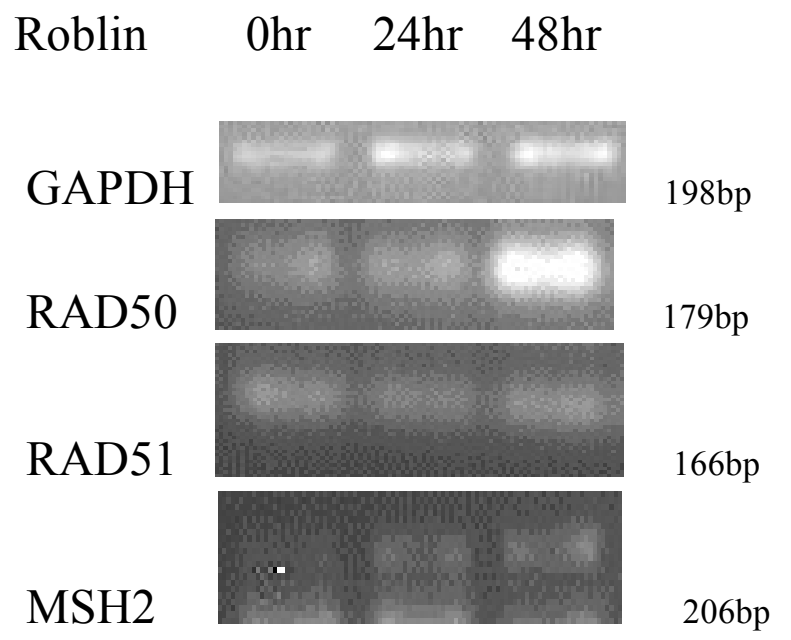

Frontana $0 \mathrm{hr} \quad 24 \mathrm{hr} \quad 48 \mathrm{hr}$
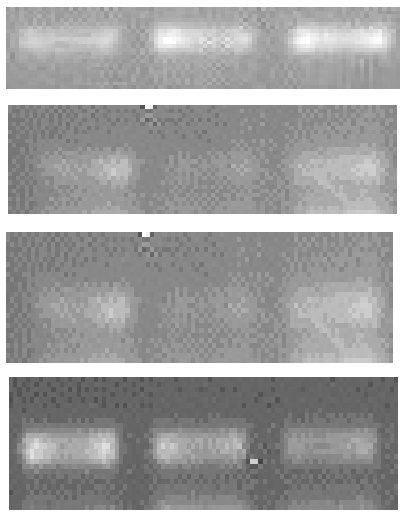
b) SA treatment
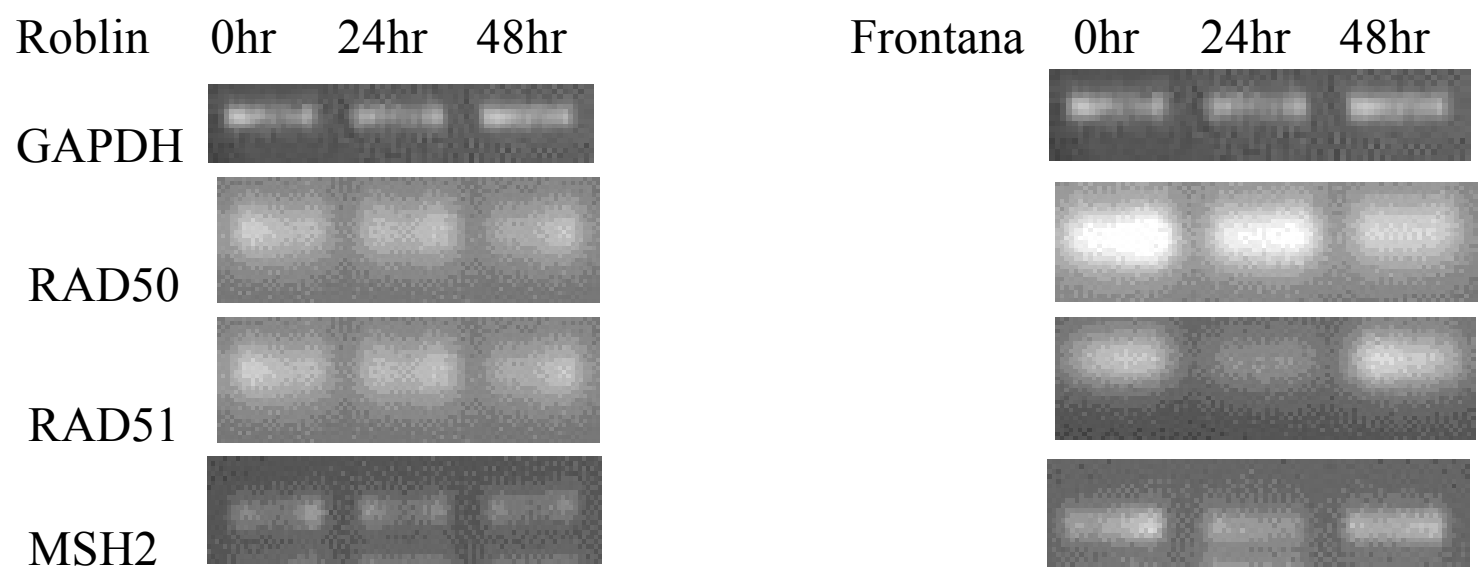
c) FB1 treatment

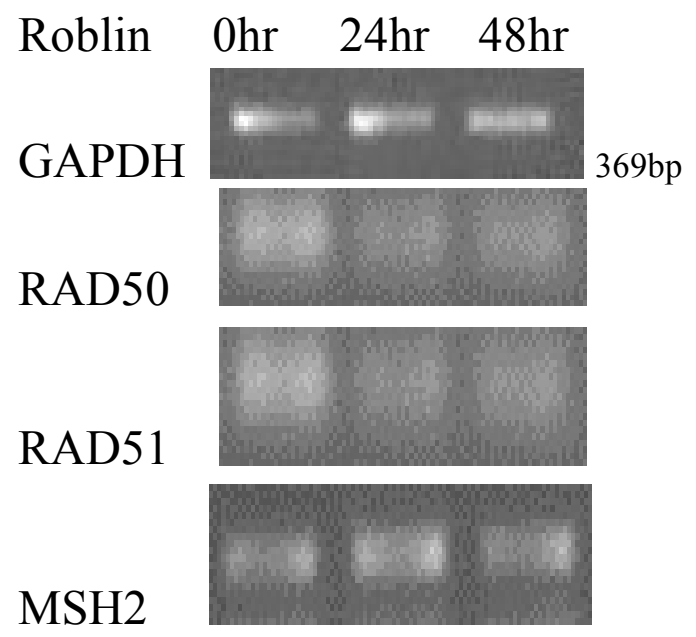

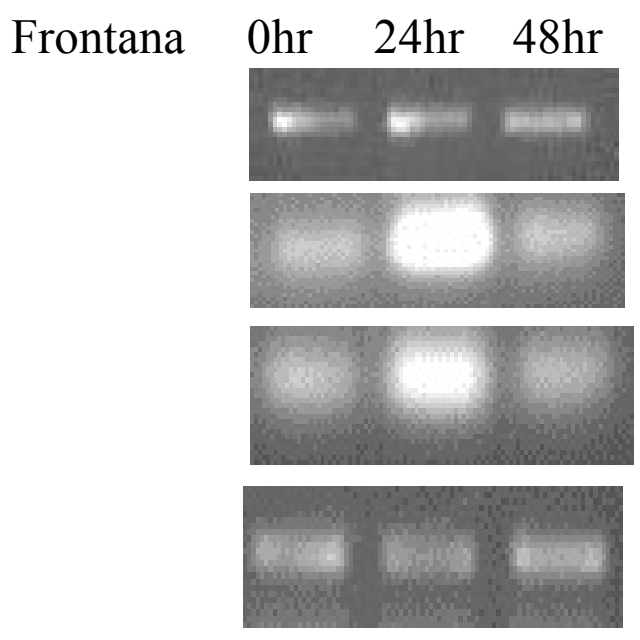


Table 3-2: DNA repairing genes with their GenBank accession numbers.

\begin{tabular}{|c|c|}
\hline GENES & GenBank accession number \\
\hline RAD50 & EU159424.1 \\
\hline RAD51 & EU915557.1 \\
\hline MSH2 & AJ131671.1 \\
\hline
\end{tabular}




\section{5. $\beta-1,3$ - Glucanase assay}

It is known that $\beta$-1, 3-glucanase is a defense enzyme (Xing, 2007). In this study, $\beta$-1, 3glucanase assay was carried out in order to see whether plants increase the production of defense enzymes and reduce the production of some of the growth-related enzymes in the case of a pathogen attack or toxin treatment.

$\beta$-1, 3-glucanase activity was measured in Roblin and Frontana after treatment with SA and FB1 for $0 \mathrm{hr}, 24 \mathrm{hr}$, and $48 \mathrm{hr}$. A spectrophotometer was used to measure the absorbance at a wavelength of $660 \mathrm{~nm}$. Statistic analysis seems to indicate that there is no significant change in the enzyme activity in the tested 48-hour period in Roblin and Frontana (Figure 3-5). Data varied in five independent experiments and the mean and standard deviation were calculated (Figure 3-5). 


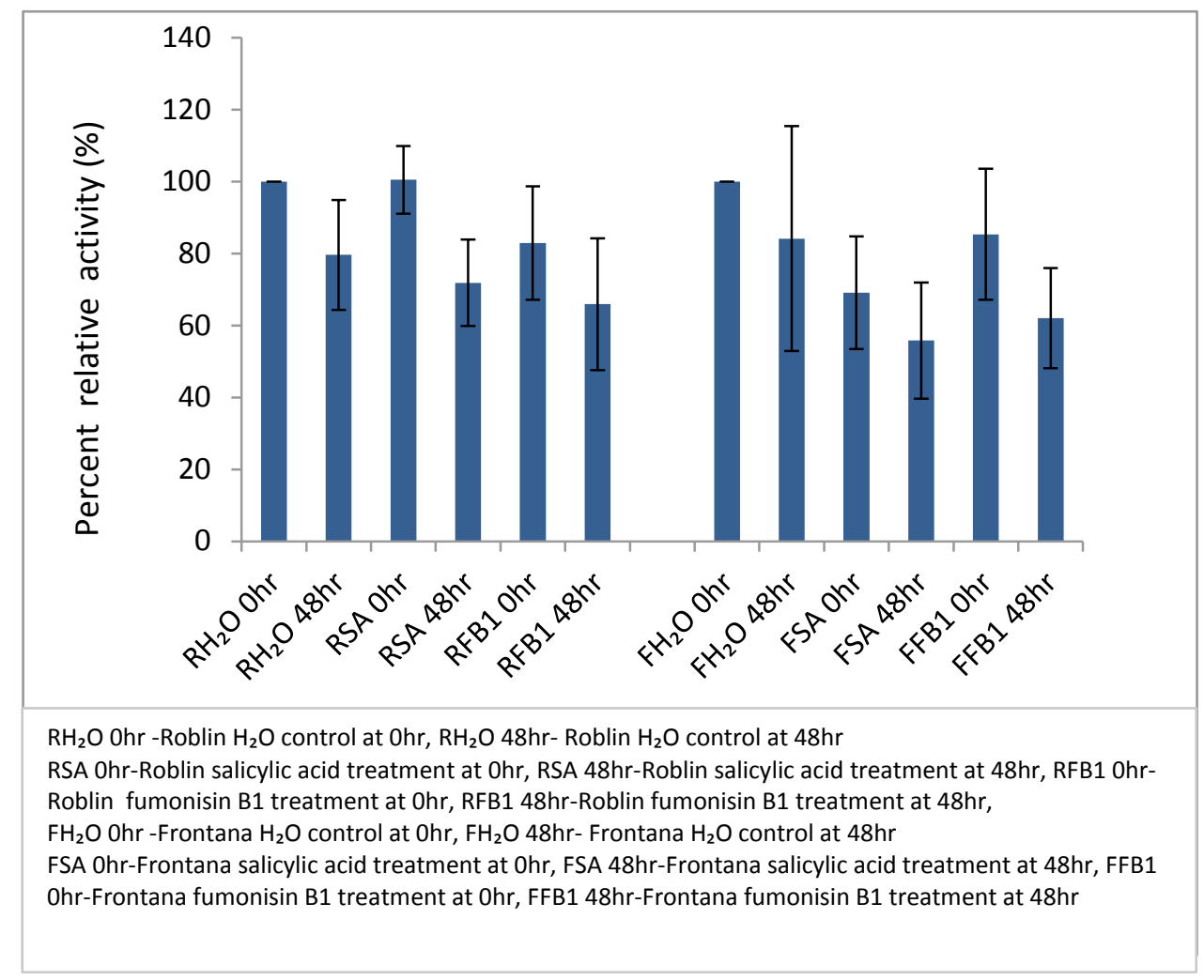

Figure 3-5: $\beta$-1, 3-glucanase enzyme activity in Roblin and Frontana leaves. $\beta$-1, 3-glucanase activity was determined according to the rate of reducing-sugar production with laminarin. A spectrophotometer was used to measure the absorbance at a wavelength of $660 \mathrm{~nm}$. Protein extraction was done using three week old Roblin and Frontana leaves treated with water, $100 \mu \mathrm{M} \mathrm{SA}$, and $5 \mu \mathrm{M}$ FB1 for $0 \mathrm{hr}, 24 \mathrm{hr}$, and $48 \mathrm{hr}$. Five independent experiments were carried out. 


\subsection{Glutamine synthetase assay}

Since we expected a metabolism shift from the vegetative growth state to a defense state during a pathogen attack, we examined GS activities in Roblin and Frontana after SA and FB1 treatment. However, data varied greatly in five independent experiments. There was no significant change in the enzyme activity in Roblin and Frontana in all the treatments (Figure 3-6). The enzyme assay should be further standardized for the stability. 


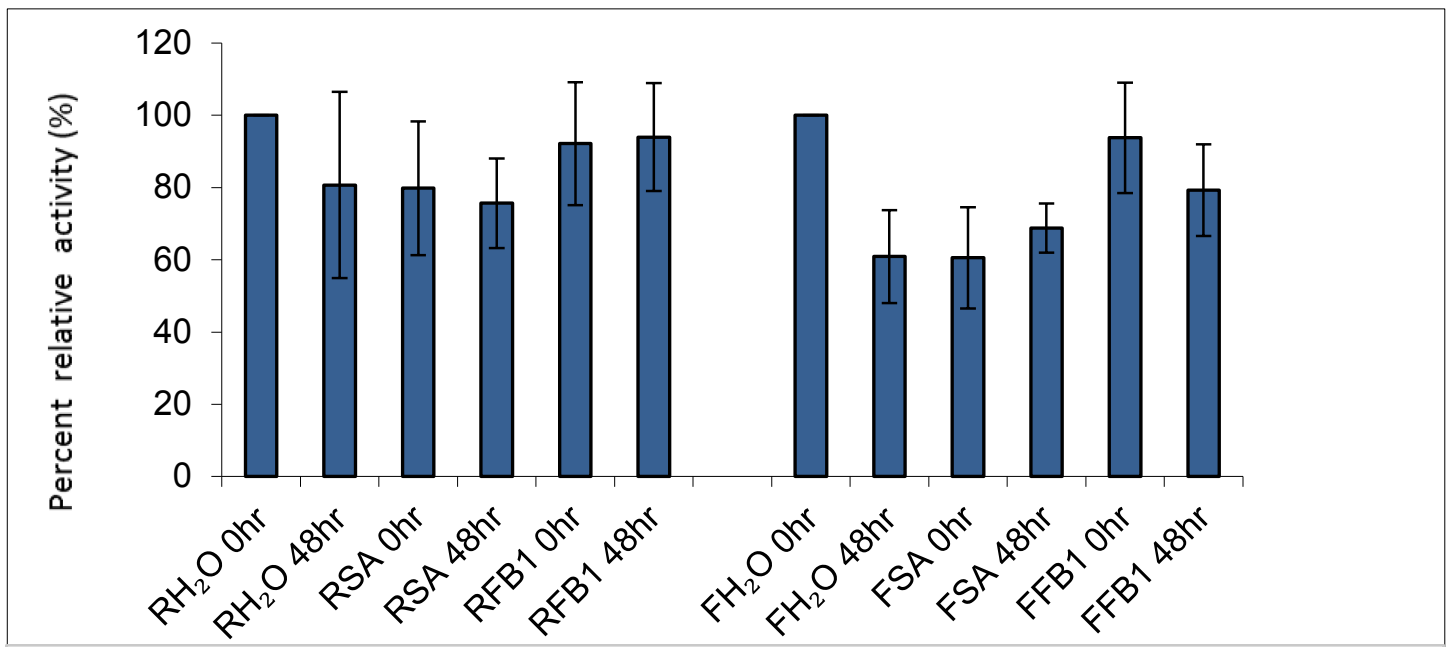

$\mathrm{RH}_{2} \mathrm{O}$ Ohr - Roblin $\mathrm{H}_{2} \mathrm{O}$ control at $\mathrm{Ohr}, \mathrm{RH}_{2} \mathrm{O} 48 \mathrm{hr}$ - Roblin $\mathrm{H}_{2} \mathrm{O}$ control at $48 \mathrm{hr}$

RSA Ohr-Roblin salicylic acid treatment at Ohr, RSA 48hr-Roblin salicylic acid treatment at 48hr, RFB1 Ohr-Roblin fumonisin B1 treatment at Ohr, RFB1 48hr-Roblin fumonisin B1 treatment at 48hr,

$\mathrm{FH}_{2} \mathrm{O}$ Ohr -Frontana $\mathrm{H}_{2} \mathrm{O}$ control at $\mathrm{Ohr}, \mathrm{FH}_{2} \mathrm{O} 48 \mathrm{hr}$ - Frontana $\mathrm{H}_{2} \mathrm{O}$ control at $48 \mathrm{hr}$

FSA Ohr-Frontana salicylic acid treatment at Ohr, FSA 48hr-Frontana salicylic acid treatment at 48hr, FFB1 0hr-Frontana

fumonisin B1 treatment at Ohr, FFB1 48hr-Frontanafumonisin B1 treatment at 48hr

Figure 3-6: Glutamine synthetase activity in Roblin and Frontana leaves. Protein was extracted from three week old Roblin and Frontana leaves treated with SA and FB1 for 0hr, $24 \mathrm{hr}$, and $48 \mathrm{hr}$. A spectrophotometer was used to measure the absorbance at $505 \mathrm{~nm}$. The data was obtained from five independent experiments. 


\subsection{SA and FB1 effects on FLR}

Three-week old wheat leaves were treated with SA and FB1. The transcript levels of FLR (GenBank accession number AY173961) did not change when the wheat leaves were treated with SA and FB1 (Figure 3-7-a-b-c).

SA is a key signaling component in the plant defense response to biotic stresses (Grant and Lamb, 2006). After SA treatment, the FLR transcript levels did not change, indicating that this gene may not be involved in SA-mediated pathways, or it could be involved at the post-translational level (Figure 3-7-b).

To study plant cell death in pathogen response pathways, FB1 has been used. In this project, the result indicates that FB1 did not induce FLR changes, suggesting that FLR transcriptional regulation may not play a role in wheat response to FB1 (Figures 3-7-c). It is possible that the MAPK cascade components are regulated at translational and posttranslational levels (Zhang et al., 2000). In the study of diverse stresses, the activation of the Arabidopsis MAPK, ATMPK4 and ATMPK6, are induced rapidly by low temperature, touch, wounding, humidity, and hyper-osmolarity. Tyrosine phosphorylation of proteins can contribute to the activation of ATMPK4 and ATMPK6 (Ichimura et al. 2000). Also, upon treatment with flagellin, a bacterial elicitor, some of the proteins were phosphorylated in Arabidopsis. Some of these phosphorylated proteins were also found to be regulated at transcriptional level (Peck, 2003).

Overall, there was no change in the FLR expression levels under SA and FB1 treatments with 30 cycles. Also, the experiment was repeated with 28 cycles and there was no change in the FLR gene expression (Figure 3-7-d-e-f). 
Figure 3-7: The effect of SA and FB1 on the FLR gene expression. RNA was extracted from Roblin and Frontana leaves treated with water, $100 \mu \mathrm{M} \mathrm{SA}$, and $5 \mu \mathrm{M}$ FB1 for $0 \mathrm{hr}$, 24hr, and 48hr. The 30 cycle RT-PCR protocol of the FLR gene was done with two biological replicates, and the same RT-PCR was performed a third batch of treatments with 28 cycles. Wheat actin (GenBank accession number AB181991) was used as the internal standard. Three experiments were carried out. The results were similar.

a) FLR gene expression in Roblin and Frontana treated with water (30 cycle)

b) FLR gene expression in Roblin and Frontana treated with SA (30 cycle)

c) FLR gene expression in Roblin and Frontana treated with FB1 (30 cycle)

d) FLR gene expression in Roblin and Frontana treated with water (28 cycle)

e) FLR gene expression in Roblin and Frontana treated with SA (28 cycle)

f) FLR gene expression in Roblin and Frontana treated with FB1 (28 cycle) 
a) Water

Roblin $\quad 0 \mathrm{hr} \quad 24 \mathrm{hr} \quad 48 \mathrm{hr}$

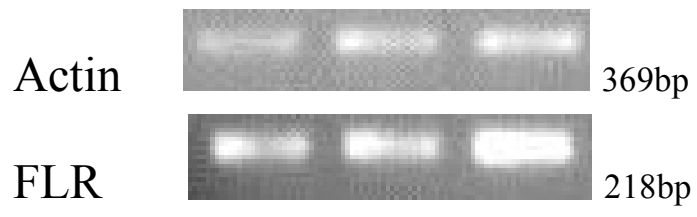

b) SA treatment

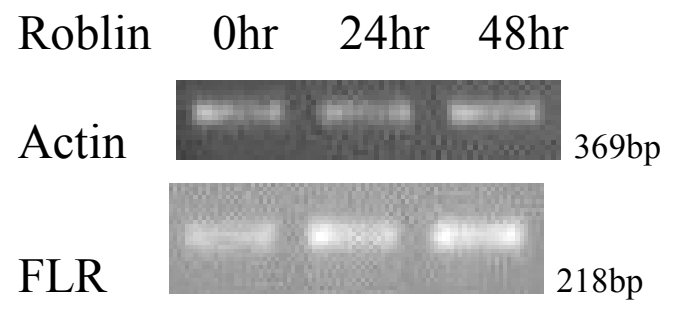

c) FB1 treatment

Roblin $\quad 0 \mathrm{hr} \quad 24 \mathrm{hr} \quad 48 \mathrm{hr}$

Actin $=369 \mathrm{bp}$

FLR

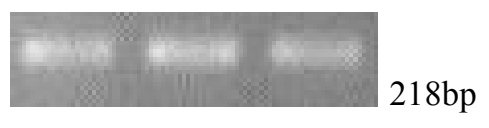

Frontana $0 \mathrm{hr} \quad 24 \mathrm{hr} \quad 48 \mathrm{hr}$

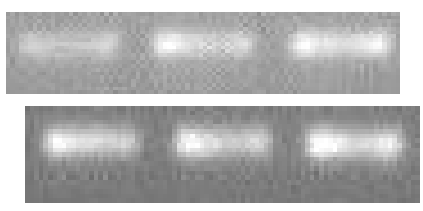

Frontana $0 \mathrm{hr} \quad 24 \mathrm{hr} \quad 48 \mathrm{hr}$

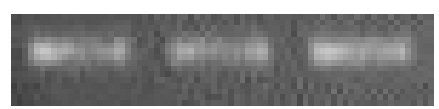

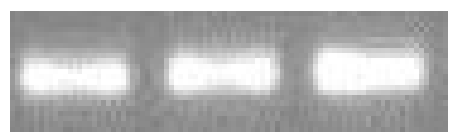

Frontana $0 \mathrm{hr} \quad 24 \mathrm{hr} \quad 48 \mathrm{hr}$

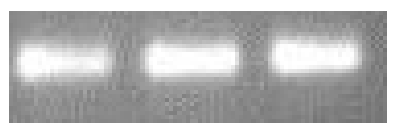


d) Water

Roblin $\quad 0 \mathrm{hr} \quad 24 \mathrm{hr} \quad 48 \mathrm{hr}$

Actin

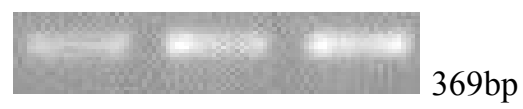

FLR

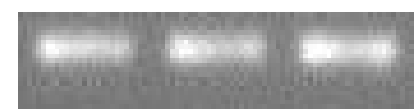

218bp
Frontana $0 \mathrm{hr} \quad 24 \mathrm{hr} \quad 48 \mathrm{hr}$
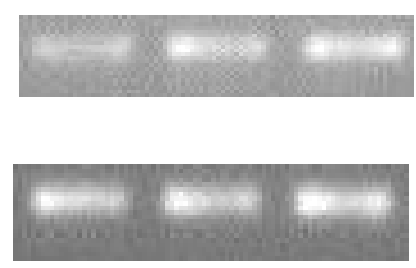

Frontana $0 \mathrm{hr} \quad 24 \mathrm{hr} \quad 48 \mathrm{hr}$

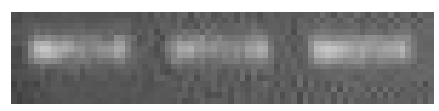

FLR $218 b p$

f) FB1 treatment

Roblin $\quad 0 \mathrm{hr} \quad 24 \mathrm{hr} \quad 48 \mathrm{hr}$

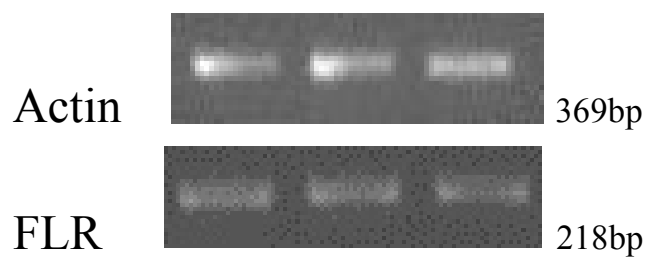

Frontana $0 \mathrm{hr} \quad 24 \mathrm{hr} \quad 48 \mathrm{hr}$
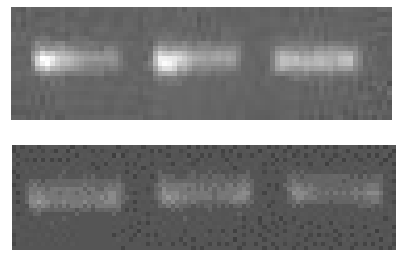


\section{Chapter IV}

\section{Discussion, Conclusion and Future Work}

\subsection{SA and FB1 induce cell death and programmed cell death in wheat}

Plants, in order to survive, possess various defense pathways when encountered by a biotic or abiotic stress. When a pathogen infects a plant, a rapid death of plant cells occurs, referred to as programmed cell death (PCD) (Beers and McDowell, 2001; Lam, 2004). Many host responses lead to the production of reactive oxygen and nitrogen species, in addition to changes in ion fluxes, activation of MAPK cascades, and proteolysis (Pozo et al., 2004). Some studies have shown that the plant hormone salicylic acid (SA) is required for many plant defense responses, while in others SA is not required (Dat et al., 2007). Our results showed that SA had no effect on Roblin (an FHB susceptible cultivar) while there was a cell death effect in Frontana (an FHB resistant cultivar) (Figure 3-1) suggesting that SA-induced cell death in Frontana could be associated with its resistance to FHB.

FB1 induces PCD in plants and animals (Asai et al., 2000). FB1 treatment caused nuclear DNA fragmentation leading to the loss of membrane integrity, which resembles apoptosis associated with PCD in animal cells (Stone et al., 2000). This activation is dosage-dependent in Arabidopsis and cell death shares many features with avirulent pathogen-induced cell death (Stone et al., 2000; Asai et al., 2000). Our results showed that FB1 induced cell death in Roblin and Frontana at an early stage. In a previous work of our lab, more cell death occurred in Roblin leaves than in Frontana leaves after a 2 to 3 days treatment with FB1, and it was suggested that early activation of host PCD in Frontana would likely limit pathogen proliferation (Gao, 2010). Also, in the same work, upon SA and FB1 treatment, the cell death levels detected by aniline blue assay and by trypan blue assay correlated well, indicating that the cell death is associated 
with callose deposition, which is triggered by ROS (Gao, 2010). When we examined the integrity of DNA in wheat leaves after biotic stress treatment by a $2 \%$ agarose gel electrophoresis, DNA laddering or smearing was not observed in wheat leaves treated by either SA or FB1, further indicating that DNA laddering may not be common in plants (De Jong et al., 2000).

\subsection{DNA repairing genes}

Chromosomal DNA breaks trigger the start of the DNA repair process to maintain genome stability, which is important for all cellular organisms. Reactive radicals, radiation and chemical mutagens can negatively affect cellular DNA stability. In response to these forms of DNA damage, DNA repairing system is activated by complex signaling pathways (Amiard et al., 2010). A sensor protein recognizes the damage and activates the transducers that send the signal to the effector proteins that activate a cellular response (Shiloh, 2006; Cimprich and Cortez, 2008).

Some of the repairing genes that were studied in this thesis include RAD50, RAD51, and MSH2. The expression level of these genes has been studied by RT-PCR in two different cultivars (a susceptible and a resistance) treated with SA or FB1. For RAD50 and RAD51, there was no change in the gene expression in either Roblin or Frontana leaves treated with SA (Figure 3-4). For leaves treated with FB1, the most significant change was observed in Frontana leaves after $24 \mathrm{hr}$ treatment and the expression of RAD50 and RAD51 increased, suggesting that DNA repairing may contribute to the defense response in Frontana. MSH2 expression, however, was not induced (Figure 3-4). Studies have shown that MSH2 forms heterodimers with other MMR

proteins during the repairing process. However, since many other MSH genes are involved, it is 
reasonable to assume that its expression may not necessarily be altered (Li, 2008; Lloyd et al., 2007).

\section{3. $\beta-1,3$ glucanase assay}

The fungal cell wall is composed of polysaccharides $\beta$ - and $\alpha$-glucans, chitin, and mannans. The structure of the fungal cell wall is a branched $\beta-1,3$-glucan cross-link to chitin. In plant fungus interactions, fungus specific molecules such as cell membrane sterols and cell wall polysaccharides can be recognized by the plants as pathogen associated molecular patterns (PAMPs) through pattern recognition receptors (PRRs) (Fujikawa et al., 2012).

Plant $\beta-1,3$-glucanase plays a critical role in the defense response. Generally, pathogenesis related genes $(P R)$ are activated by plant-pathogen interactions leading to the expression of PR proteins including $\beta$-1,3-glucanases. The $\beta$-1, 3-glucan linker component of the fungal cell wall is hydrolyzed by $\beta$-1, 3-glucanases. Many $\beta$-1, 3-glucanases inhibit the fungal growth in vitro. It has been shown that overexpressing $\beta$-1, 3-glucanase gene increased resistance against fungal pathogens (Liu et al., 2009).

In my work, the effect of SA and FB1 treatments on an FHB susceptible and an FHB resistant cultivar has been studied. There is no significant change in the $\beta-1,3$-glucanase activity in either Roblin or Frontana (Figure 3-5). It was expected that there would be an increase in the $\beta-1,3$-glucanase enzyme activity under the FB1 treatment in Frontana. However, the results obtained from five biological repeat experiments did not agree with our hypothesis. Thus, further studies will be done in the future.

\subsection{Glutamine synthetase}

Glutamine synthetase has two isoforms: a cytosolic GS1, which is involved in nitrogen remobilization, and a chloroplastic GS2, which is involved in nitrogen assimilation (Pegeau et al., 2006). GS is involved in the reassimilation of ammonium released by a number of 
biochemical processes such as protein catabolism, deamination of amino acids, and photorespiration (Seabra et al., 2010). The effects of SA and FB1 on glutamine synthetase activity have been studied in Roblin and Frontana. The results showed that glutamine synthetase activity did not change significantly in response to SA or FB1 treatment (Figure 3-6). It was assumed that GS decreases after the treatments since the infected plants may slow down its production. GS isoforms are determined by different nuclear genes (Perez-Garcĺa et al., 1998). GS isoforms play non overlapping physiological roles in plant metabolism when it is expressed in different cell types (PeÂrez-GarcõÂa et al., 1998). In angiosperms, there is a cytosolic isoform (GS1) and a chloroplast located isoform (GS2). GS1 could be involved in the generation of glutamine for nitrogen transport when it is associated with phloem cells (Carvalho et al., 1992; Kamachi et al., 1992). Tomato plants present high levels of GS2 in response to infection, suggesting that it may contribute to the development of disease symptoms or defense responses. In response to bacterial infection, GS expression changed and different isoforms of cytosolic GS were induced (PeÂrez-GarcõÂa et al., 1998). Our data do not agree with the hypothesis and further studies are needed.

\subsection{FLR gene}

In a MAPK cascade, an MAPKKK activates MAPKKs, and then an MAPKK activates downstream MAPKs. Multiple members have been found at each cascade level in model plants such as Arabidopsis and rice. In a rice study, 75 MAPKKKs were identified and they are grouped into subtypes including Raf, MEKK, and ZIK (Rao et al., 2010). FLR belongs to ZIK family (Gao, 2010), since the conserved signature 'GTPEFMAPE' motif was found on its sequences (Rao et al., 2010). Serine and serine/threonine residues in the S/TXXXXXS/T motif are phosphorylated by MAPKKKs, leading to the activation of MAPKKs in the MAPK cascade 
(Ichimura et al., 1998). Gao et al. (2010) illustrated that amino acid residues 30 to 301 in FLR are recognized as a potential serine/threonine protein kinase domain, suggesting that FLR is a kinase and may phosphorylate downstream serine/threonine kinases. An alignment analysis has also indicated that a Homo sapiens MAPKKK and FLR both have a ZIK signature motif (Gao, 2010).

Acting as an endogenous signal, SA induces systemic acquired resistance (SAR) (Grant and Lam, 2006). In transgenic tobacco plants harboring salicylate hydroxylase, a bacterial gene, the contribution of SA to systemic acquired resistance was explored (Gaffney et al., 1993). As the transgenic plants rapidly hydroxylated endogenous SA, the SAR response could not be induced against tobacco mosaic virus attack (Gaffney et al., 1993; Glazebrook, 1999; Grant and Lamb, 2006). SA is not required for some plant defense responses even though it is important in many other cases. Figure 3-7-b shows the expression of FLR after SA treatment. FLR may not be involved in SA-mediated pathways since there was no change in the mRNA level of FLR.

FB1, a PCD-eliciting mycotoxin, is also used as a biotic stress in this study. There was no change in the expression levels of FLR under the FB1 treatment (Figure 3-7-c), suggesting that transcriptional regulation of FLR may not play a role in wheat response to FB1.

MAPK cascade components are structured at multiple levels and each level of components can be regulated at the transcriptional, translational and post-translational levels (Xing and Laroche, 2011). One or more covalent modifications of the polypeptide chain can create diverse variations of a protein. Modifications such as acetylation, glycosylation, phosphorylation, isoprenylation, and others result in hundreds of variant amino acids (Roberts, 2002). In response to a pathogen attack, protein phosphorylation is one of the most predominant posttranslational modifications in plants and in many organisms. A few proteins that were 
phosphorylated in Arabidopsis upon treatment with flagellin, a bacterial elicitor, were found to be critical for the elicitor induced defense responses (Peck, 2003; Xing and Laroche, 2011).

The relative contribution of transcriptional, translational and post-translational modification to the overall response, might be different. During the induction of cell death by a fungal elicitor, the tobacco WIPK gene (wound-induced protein kinases; which encodes a MAPK) is activated at several stages (Zhang et al., 2000). In order to activate kinase activity and the onset of hypersensitive-response (HR)-like cell death, de novo transcription and translation are necessary (Zhang et al., 2000). Some stresses induce quick activation of Arabidopsis MAP kinase ATMPK4 and ATMPK6 such as touch, wounding, hyper-osmolarity, low humidity, and low temperature (Ichimura et al., 2000). Activation of ATMPK4 and ATMPK6 was not associated with the amounts of mRNA or protein but with tyrosine phosphorylation (Peck, 2003). Rudd et al. (2008) demonstrated that during a defense response wheat mitogen-activated protein kinases, TaMPK3 and TaMPK6, were regulated at multiple levels.

\subsection{Conclusion and future work}

In my thesis, several possible defense mechanisms were studied in Roblin, a susceptible wheat cultivar to FHB, and Frontana, a resistant cultivar to FHB. FB1 seemed to induce a necrosis type of cell death in both Roblin leaves and Frontana leaves, and the cell death was associated with concurrent accumulation of ROS. However, there was no DNA laddering in Roblin and Frontana. Gene expression analysis of DNA repairing genes RAD50, RAD51, and MSH2 has suggested that enhanced expression of RAD50 and RAD51 may contribute to FHB resistance in Frontana. Wheat FLR gene, which encodes a MAPKKK kinase was studied. At transcriptional level, FLR did not respond to SA or FB1. 
Cell death was detected microscopically in this work. For future work, another method that can be used for cell death detection is a lactate dehydrogenase (LDH). LDH was found in animals and plants. This assay can detect cell death that occurs via necrosis (Chan et al., 2013; Lobner, 2000). Also, viable and dead cells can be distinguished by fluorescent dyes such as calcein-acetoxymethyl (calcein-AM) and ethidium homodimeer-1 or propidium iodide (PI). Calcein-AM is membrane permeable, but not fluorescent. It can trigger the living cells to generate fluorescent calcein, producing a green fluorescence. PI can be applied to identify dead cell. When PI enters the damaged cells and binds to nucleic acid, it generates a bright red fluorescence (Zhou et al., 2010). Also, to detect DNA damage, TUNEL, dUTP nick end labeling, will be useful. All these additional methods would help to further confirm the cell death work in this thesis.

FLR did not change at transcriptional level in this work. In order to test its activity such as phosphorylation of its substrates, we may need to study the phosphorylation levels of its substrates upon SA and FB1 treatments.

It is hoped that our study on RAD50, RAD51 or FLR could lead to a strategy development for the manipulation of plant disease resistance to pathogen attacks. 


\section{REFERENCES:}

1. Abdelnoor, R.V., Yule, R., Elo, A., Christensen, A.C., Meyer-Gauen, G., and Mackenzie, S.A. Substoichiometric shifting in the plant mitochondrial genome is influenced by a gene homologous to MutS. Proc. Nat. Acad. Sci. USA 2003, 100: 5968-5973.

2. Amiard, S., Charbonnel, C., Allain, E., Depeiges, A., White, C.I., and Gallego, M.E. Distinct roles of the ATR kinase and the Mre11-Ras50-Nbs1 complex in the maintenance of chromosomal stabiliy in Arabidopsis. The Plant Cell. 2010, 22: 3020-3033.

3. Asai, T., Stone, J.M., Heard, J.E., Kovtun, Y., Yorgey, P., Sheen, J., and Ausubel, F.M. Fumonisin B1-induced cell death in Arabidopsis protoplasts requires jasmonate-, ethylene-, and salicylic-dependent signaling pathways. Plant Cell. 2000, 12: 1823-1835.

4. Asai, T., Tena, G., Plotnikova, J., Willman, M.R., Chiu, W.L., Gomez-Gomez, L., Boller, T., Asubel, F.M., and Sheen, J. MAP kinase signaling cascade in Arabidopsis innate immunity. Nature 2002, 415: 977-983.

5. Balk, J., Leaver, C.J., and McCabe, P.F. Translocation of cytochrome c from the mitochondria to the cytosol occurs during heat-induced programmed cell death in cucumber plants. FEBS Lett. 1999, 463: 151-154.

6. Barzel, A. and Kupiec, M. Finding a match: How do homologous sequences get together for recombination?. Nat. Rev. Genet. 2008, 9: 27-37.

7. Beers, E.P. and McDowell, J.M. Regulation and execution of programmed cell death in response to pathogen, stress and developmental cues. Cur. Op. Plant Biol. 2001, 4(6): 561-567

8. Bioshop, D.K., Park, D., Xu, L., and Kleckner, N. DMC1: A meiosis-specific yeast homolog of $\mathrm{E}$, coli $\operatorname{rec} A$ required for recombination, synaptonemal complex formation, and cell cycle progression. Cell. 1992, 69: 439-456. 
9. Bohnert, H.J., Nelson, D.E., and Jensen, R.G. Adaptations to environmental stresses. Plant Cell. 1995, 7: 1099-1111.

10. Bolton, M.D. Primary metabolism and plant defense--fuel for the fire. Mol Plant Microbe Interact. 2009, 22(5): 487-497.

11. Bray, C.M. and West, C.E. DNA repair mechanisms in plants: crucial sensors and effectors for the maintenance of genome integrity. New Phytol. 2005, 168:511-528. Iyer RR, Pluciennik A et al DNA mismatch repair: functions and mechanisms. Chem Rev. 2006, 106:302-323.

12. Carvalho, H., Pereira, S., Sunkel, C., and Salema, R. Detection of cytosolic glutamine synthetase in leaves of Nicotiana tabacum L. by immunocytochemical methods. Plant Physiol. 1992, 100: 1591-1594.

13. Cheong, Y.H., Moon, B.C., Kim, J.K., Kim, C.Y., Kim, M.C., Kim, I.H., Park, C.Y., Kim, J.C., Park, B.O., Koo, S.C., Yoon, H.W., Chung, W.S., Lim, C.O., Lee, S.Y., and Cho, M.J. BWMK1, a rice mitogen-activated protein kinase, locates in the nucleus and mediates pathogenesis-related gene expression by activation of transcription factor. Plant Physiol. 2003, 132: 1961-1972.

14. Chan, F.K., Moriwaki, K., and De Rosa, M.J. Detection of necrosis by release of lactate dehydrogenase activity. Methods. Mol. Biol.2013, 979; 65-70.

15. Cimprich, K.A. and Cortez, D. ATR: An essential regulator of genome integrity. Nat. Rev. Mol. Cell Biol. 2008, 9:616-627.

16. Coll, N.S., Epple, P., and Dangl, J.L. Programmed cell death in plant immune system. Cell Death and Differentation 2011, 18; 1247-1256.

17. Cvetkovska, M., Rampitsch. C., Bykova. N., and Xing, T. Genomic analysis of MAP kinase cascades in Arabidopsis defense responses. Plant Mol. Biol. Rep. 2005, 23: 331-343. 
18. Czornak, K., Chughtai, S., and Chrazanowska, K.H. Mystery of DNA repair: The role of the MRN complex and ATM kinase in DNA damage repair. J. Appl. Genet. 2008, 49: 383-396.

19. Danon, A., Delorme, V., Mailhac, N., and Gallois, P. Plant programmed cell death: a common way to die. Plant Physiol. Biochem. 2000, 38: 647-655.

20. Dat, J.F., Capelli, N., and Breusegem, F.V. The interplay between salicylic acid and reactive oxygen species during cell death in plants. S. Hayat and A. Ahmad (eds), Salicylic Acid-A PlantHormone, 2007, (pp. 247-276). Netherlands: Springer.

21. De Jong, A.J., Hoeberichts, F.A., Yakimova, E.T., Maximova, E., and Woltering, E.J. Chemical-induced apoptotic cell death in tomato cells: involvement of caspase-like proteases. Planta. 2000, 211: 656-662.

22. Delaney, T.P., Uknes, S., Vernooij, B., Friedrich, L., Weymann, K., Negrotto, D., Gaffney, T., Gut-Rella, M., Kessmann, H., Ward, E., and Ryals, J. A central role of salicylic acid in plant disease resistance. Science 1994, 266: 1247-1250.

23. Depeiges, A., Farget, S., Degroote, F., and PICARD, G. A new transgene assay to study microsatellite instability in wild-type and mismatch-repair defective plant progenies. Plant Science 2005, 168: 939-947.

24. Desai, K., Sullards, M.C., Allegood, J., Wang, E., Schmelz, E.M., Hartl, M., Humpf, H.U., Liotta, D.C., Peng, Q., and Merrill, H.A. Fumonisins and fumonisin analogs as inhibitors of ceramide synthase and inducers of apoptosis. Biochimica et Biophysica Acta-Mol. Cell Biol. Lipids. 2002, 1585: 188-192.

25. Devisetty, U.K., Mayes, K., and Mayes, S. The RAD51 and DMC1 homologous genes of bread wheat: cloning, molecular characterization and expression analysis. BMC Research Notes. 2010, 3: 245. 
26. Duan, Y., Zhang, W., Li, B., Wang, Y., Li, K., Sodmergen, Han, C., Zhang, Y., and Li, X. An endoplasmic reticulum response pathway mediates programmed cell death of root tips induced by water stress in Arabidopsis. New Phytol. 2010, 186: 681-695.

27. Ellis, R.E., Yuan, J., and Horvitz, H.R. Mechanism and functions of cell death. Annu. Rev. Cell Biol. 1991, 7: 663-698.

28. Emmanuel, E., Yehuda, E., Melamed-Bessudo, C., Avivi-Ragolsky, N., and Levy, A.A. The role of AtMSH2 in homologous recombination in Arabidopsis thaliana. EMBO report. 2006, 7 (1).

29. Fan, T., Gao, A., Al-Shammari, A., Wang, J., and Xing, T. Yeast two-hybride screening of MAP kinase cascade identifies cytosolic glutamine synthetase $1 \mathrm{~b}$ as a tMEK2 interactive protein in wheat. Can. J. Plant. Pathology. 2009, 31: 407-414.

30. Fan, T. and Xing, T. Heat shock induces programmed cell death in wheat leaves. Biol. Plant. 2004, 48: 389-394.

31. Flor, H.H. Current status of the gene-for-gene concept. Annu. Rev. Phytopathol. 1971, 9: 275296.

32. Fujikawa, T., Sakaguchi, A., Nishizawa, Y., Kouzai, Y., Minami, E., Yano, S., Koga, H., Meshi, T., and Nishimura, M. Surface alpha-1,3-Glucanase facilitates fungal steath infection by interferring with innate immunity in plants. PLOS Pathogens www.plospathogens.org. 2012, 8: e1002882.

33. Futerman, A.H. Inhibition of sphingolipid synthesis: effect on glycosphingolipid-GPI anchored protein microdomains. Trends Cell Biol. 1995, 5: 377-380

34. Gaffney, T., Friedrich, L., Vernooij, B., Negrotto, D., Nye, G., Uknes, S., Ward, E., Kessmann, H., and Ryals, J. Requirement of salicylic acid for the induction of systemic acquired resistance. Science. 1993, 261: 754-756. 
35. Gallego, M.E. and White, C.I. RAD50 functionis essential for telomere maintenance in Arapidopsis. Proc. Natl. Acad. Sci. USA. 2001, 98: 1711-1716.

36. Gao, Y. Wheat mitogen-activated protein kinase pathways in plant defense response. M.Sc. Thesis 2010, Carleton University. Ottawa, Canada.

37. Gilchrist, D.G. Programmed cell death in plant disease: The purpose and promise of cellular suicide. Annu. Rev. Phytopathol. 1998, 36: 393-414.

38. Gillbert, J. and Tekauz, A. Recent developments in research on fusarium head blight of wheat. Can. J. Plant Pathol. 2000, 22: 1-8.

39. Gillbert, J., Jordan, M., Somers, D., Xing, T., and Punja, Z. Engineering plants for durable disease resistance. S. Tuzun and E. Bent (eds). Multigenic and Induced Systemic Resistance in Plants 2006, 415-455. US: Springer.

40. Glazebrook, J. Genes controlling expression of defense responses in Arabidopsis. Cur. Op. Plant Biol. 1999, 2: 280-286.

41. Grant, M. and Lamb, C. Systemic immunity. Cur. Op. Plant Biol. 2006, 9: 414-420.

42. Greenberg, J.T. Programmed cell death: A way of life for plants. Proc. Natl. Acad. Sci. 1996, 93: 12094-12097.

43. Greenberg, J.T. and Yao, N. The role and regulation of programmed cell death in plantpathogen interactions. Cell Microbiol. 2004, 6: 201-211.

44. Gunawardena, A.H.L.A.N., Greenwood, J.S., and Dengler, N.G. Programmed cell death remodels lace plant leaf shape during development. Plant Cell. 2004, 16: 60-73.

45. Gygi, S.P., Rochon, Y., Franza, B.R., and Aebersold, R. Correlation between protein and mRNA abundance in yeast. Mol. Cell Biol. 1999, 19: 1720-1730. 
46. Hamel, L.P., Nicole, M.C., Sritubtim, S., Morency, M.J., Ellis, M., Ehlting, J., Beaudoin, N., Barbazuk, B., Klessig, D., Lee, J., Martin, G., Mundy, J., Ohashi, Y., Scheel, D., Sheen, J., Xing, T., Zhang, S., Seguin, A., and Ellis, B.E. Ancient signals: comparative genomics of plant MAPK and MAPKK gene families. Trends Plant Sci. 2006;11:192-198.

47. Hirt, H. Multiple roles of MAP kinases in plant signaling transduction. Trends. Plant Sci. 1997, 2:11-15.

48. Hunter, N., Chambers, S.R., Louis, E.J., and Borts, R.H. The mismatch repair system contributes to meiotic sterility in an interspecific yeast hybrid. EMBO J. 1996, 15: 1726-1733.

49. Ichimura, K., Mizoguchi, T., Hayashida, N., Seki, M., and Shinozaki, K. Molecular cloning and characterization of three cDNA encoding putative mitogen-activated kinase kinase (MAPKKs) in Arabidopsis thaliana. DNA Res. 1998, 5: 341-348.

50. Ichimura, K., Mizoguchi, T., Yoshida, R., Yuasa, T., and Shinozaki, K. Various abiotic stresses rapidly activated Arabidopsis MAP kinase AtMPK4 and AtMPK6. Plant. J. 2000, 24: 655-665.

51. Ichimura, K., Shinozaki, K., Tena, G., Sheen, J., Henry, Y., Champion, A., Kreis, M., ZHANG, S., Hirt, H., Wilson, C., Heberle-Bors, E., Ellis, B., Morris, P.C., Innes, R.W., Ecker, J.R., Scheel, D., Klessig, D.F., Machida, Y., Mundy, J., Ohashi, Y., and Walker, J.C. Mitogenactivated protein kinase cascades in plants: A new nomenclature. Trends. Plant Sci. 2002, 7: 301-308.

52. Iyer, R.R., Pluciennik, A., Burdett, V., and Modrich, P.L. DNA mismatch repair: functions and mechanisms. Chem Rev. 2006, 106:302-323.

53. Jin, Y-F. and Bian, T-J. Isolation and expression of a wheat pollen-specific gene with long leader sequence. Acta Botanica Sinica 2004, 46 (11): 1347-1356. 
54. Jonak, C., Ligterink, W., and Hirt, H. MAP kinase in plant signal transduction. Cell. Mol Life Sci. 1999, 55: 204-213.

55. Jonak, C., Okresz, L., Bogre, L., and Hirt, H. Complexity, Cross talk and integration of plant MAP kinase signalling. Cur. Op. Plant Biol. 2002, 5: 415-424.

56. Jones, A.M. and Dangl, J.L. Logjam at the styx: programmed cell death in plants. Trends Plant Sci. 1996, 1: 114-119.

57. Jones, A.M. Does the plant mitochondrion integrate cellular stress and regulate programmed cell death? Trends Plant Sci. 2000, 5: 225-230.

58. Jones, A.M. Programmed cell death in development of defense. Plant Physiol. 2001, 125: 9497.

59. Jordan, M., Cloutier, S., Somers, D., Procunier, D., Rampitsch, C., and Xing, T. Beyond R gene: dissecting disease-resistance pathways using genomics and proteomics. Can. J. Plant Pathol. 2006, 28s: 228-232.

60. Kamachi, K., Yamaya, T., Hayakawa, T., Mae, T., and Ojima, K., Vascular bundle-specific localization of cytosolic glutamine synthetase in rice leaves. Plant Physiol. 1992, 99: 14811486.

61. Khoo, K.H.P., Jolly,H.R., and Able,J.A. The RAD51 gene family in bread wheat is highly conserved across eukaryotes, with RAD51A upregulated during early meiosis. Funct. Plant Biol. 2008, 35: 1267-1277.

62. Kim, Y.J., Lin, N.C., and Martin, G.B. Two distinct Pseudomonas effector proteins interact with the Pto kinase and activate plant immunity. Cell. 2002, 109: 589-598.

63. Kolmer, J.A. Genetics of resistance to wheat leaf rust. Ann. Rev. Phytopathol. 1996, 34: 435455. 
64. Kornberg, A. and Bake, T.A. DNA Replication. New York, USA: WH Frreeman (1992).

65. Koukalovā, B., Kovarik, A., Fajkus, J., and Siroky, J. Chromatin fragmentation associated with apoptotic in tobacco cells exposed to cold stress. FEBS Lett. 1997, 414: 289-292.

66. Krasileva, K.V., Dahlbeck, D., and Staskawicz, B.J. Activation of an Arabidopsis Resistance Protein Is Specified by the in Planta Association of Its Leucine-Rich Repeat Domain with the Cognate Oomycete Effector. Plant Cell. 2010, 22: 2444-2458.

67. Lam, E., Kato, N., and Lawton, M. Programmed cell death, mitochondria and the plant hypersensitive response. Nature. 2001, 411: 848-853.

68. Lam, E. Controlled cell death, plant survival and development. Nature Review Mol. Cell Biol. 2004, 5: 305-315.

69. Leonard, J.M., Bollmann, S.R., and Hays, J.B. Reduction of stability of Arabidopsis genomic and transgenic DNA-repeat sequences (microsatellites) by inactivation of AtMSH2 mismatchrepair function. Plant Physiol. 2003, 133: 328-338.

70. Lmarche, B.J., Orazio, N.I., and Weitzman, M.D. The MRN complex in douple-strand breaks repair and telomere maintenance. FEBS Lett. 2010, 584: 3683-3695.

71. Li, G.M. Mechanisms and functions of DNA mismatch repair. Cell Research. 2008, 18: 85-98.

72. Lieberherr, D., Thao, N.P., Nakshima, A.K., Umemura, K., Kawasaki, T., and Shimamoto, K. A shingolipid elicitor-inducible mitogen-activated protein kinase is regulated by the small GTPase OsRac1 and heterotrimeric G- protein in rice. Plant Physiol. 2005, 138: 1644-1652.

73. Liu, B., Lu, Y., Xin, Z., and Zhang, Z. Identification and antifungal assay of a wheat $\beta-1,3-$ glucanase. Biotechnol. Lett. 2009, 31: 1005-1010.

74. Lloyd, A.H., Milligan, A.S., Langridge, P., and Able, J. TaMSH7: A careal mismatch repair gene that affects fertility in transgenic barley (Hordeum vulgare L). BMC Plant Bio 2007, 7:67. 
75. Lobner, D. Comparison of the LDH and MTT assays for quantifying cell death: validity for neuronal apoptosis. J. Neuroscience Methods. 2000, 96: 147-152.

76. Luan, S. Tyrosine phosphorylation in plant cell signaling. Proc. Natl. Acad. Sci. USA 2002, 99: $11567-11569$.

77. Man, H., Pollmann, S., Weiler, E.W., and Kirby, E.G. Increased glutamine in leaves of poplar transgenic with pine GS1 a caused greater anthranilate synthetase alpha-subunit (ASA1) transcript and protein abundances: an auxin-related mechanism for enhanced growth in GS transgenics. J. Exp.Bot. 2011, 62: 4423-4431.

78. Mizoguchi, T., Ichimura, K., and Shinozaki, K. Environmental stress response in plants: The roles of mitogen-activated protein kinase. Trends Biotechnol. 1997, 15: 15-19.

79. Modrich, P. and Lahue, R. Mismatch repair in replication fidelity genetic rrecombination, and cancer biology. Annu. Rev. Biochem. 1996, 65: 101-133.

80. Morris, K., Mackerness, S.A., Page, T., John, C.F., Murphy, A.M., Carr, J.P., and BushananWollaston, V. Salicylic acid has a role in regulating gene expression during leaf senescence. Plant J. 2000, 23: 677-685.

81. Munne-Bosch, S. and Alegre, L. Die and let live: leaf senescence contributes to plant survival under drought stress. Funct. Plant. Biol. 2004, 31: 203-216.

82. Mungur, R., Glass, A.D.M., Goodenow, D.B., and Lightfoot, D.A. Metabolite fingerprinting in transgenic Nicotiana tabacum altered by the Escherichia coli glutamate dehydrogenease gene. J. Biotechnol. 2005, 2: 198-214

83. Newton, A.C. Regulation of the $\mathrm{ABC}$ kinases by phosphorylation: protein kinase $\mathrm{C}$ as a paradigm. Biochem J. 2003, 370: 361-371.

84. Nickels, J.T. and Broach, J.R. A ceramide-activated protein phosphatase mediates ceramide- 
induced G1 arrest of Saccharomyces cerevisiae. Genes \& Dev. 1996, 10: 382-394.

85. Nimchuk, Z., Eulgem, T., Holt, B.F., and Dangl, J.L. Recognition and response in the plant immune system. Аnпu. Rev. Genet. 2003, 37: 579-609.

86. Niu, J.S., Zhang, L.N., Zhuang, L.F., and Wang, Y.H. Inheritance of the powdery mildew resistance in wheat line "99-2439". Chin. Bull. Bot. 2005, 22(4):439-444.

87. Ning, S., Wang, L., and Song, Y. Identification of programmed cell death in situ in individual plant cell in vivo using a chromosome preparation technique. J. Exp. Bot. 2002, 369: 651-658.

88. Nishihama, R., Banno, H., Shibata, W., Hirano, K., Nakashima, M., Usami, S., and Machida, Y. Plant homologues of components of MAPK (mitogen-activated protein kinase) signal pathways in yeast and animal cells. Plant Cell Physiol. 1995, 36: 749-757.

89. PeÂrez-GarcõÂa, A., Pereira, S., Pissarra, J., GarcõÂa GutieÂrrez, A., Cazorla1, F.M., Salema, R., de Vicente, A., and CaÂ novas, F.M. Cytosolic localization in tomato mesophyll cells of a novel glutamine synthetase induced in response to bacterial infection or phosphinothricin treatment. Planta. 1998, 206: 426-434.

90. Peck, S.C. Early phosphorylation events in biotic stress. Cur. Op. Plant Biol. 2003, 6: 334-8.

91. Pedley, K.F., and Martin, G.B. Identification of MAPKs and their possible MAPK kinase activators involved in the Pto-mediated defense response of tomato. J. Biol. Chem. 2004, 279: $49229-49235$.

92. Petit, M.A., Dimpfl, J., Radman, M., and Echols, H. Control of large chromosomal duplication in Escherichia coli by the mismatch repair system. Genetics. 1991, 129: 327-332.

93. Pontier, D., Balague, C., and Roby, D. The hypersensitive response: A programmed cell death associated with plant resistance. Comptes Rendus de l'Academie des Sciences, Series III. Sciences de la Via. 1998, 321: 721-734. 
94. Pozo, O.D., Pedley, K.F., and Martin, G.B. MAPKKK $\alpha$ is a positive regulator of cell death associated with both plant immunity and disease. EMBO. J. 2004, 23: 3072-3082.

95. Plett, J.M., Cvetkovska, M., Makenson, P., Xing, T., and Regan, S. Arabidopsis ethylene receptors have different roles in Fumonisin B1-induced cell death. Physiol. Mol. Plant Pathol. 2009, 74: 18-26.

96. Rao, K.P., Richa, T., Kumar, K., Reghuram, B., and Sinha, A.K. In silico analysis reveals 75 members of mitogen-activated protein kinase kinase kinase gene family in rice. DNA Rev. 2010, 17: 139-153.

97. Reyna, N.S. and Yang, Y. Molecular analysis of the rice MAP kinase gene family relation to Magnaporthe grisea infection. Mol. Plant Microb. Interact. 2006, 19: 530-540.

98. Rich, T., Allen, R.L., and Wyllie, A.H. Defying death after DNA damage. Nature. 2000, 407 : 777-783.

99. Roberts, J.K.M. Proteomics and a future generation of plant molecular biologists. Plant Mol Biol. 2002, 48: 143-154.

100. Rudd, J.J., Keon, J., and Hammond-Kosack, K.E. The wheat mitogen-activated protein kinases TaMPK3 and TaMPK6 are differentially regulated at multiple levels during compatible disease interactions with Mycosphaerella graminicola. Plant Physiol. 2008, 147: 802-815.

101. Schubert, I., Pecinka, A., Meister, A., Schubert, V., Klatte, M., and Jovtchev, G. DNA damage processing and aberration formation in plants. Cytogenet. Genome Res. 2004, 104: 104-108.

102. Seabra, A.R., Vieira, C.P., Cullimore, J.V., and Carvalho, H.G. Medicago truncatula contains a second gene encoding a plastid located glutamine synthetase exclusively expressed in developing seeds. BMC Plant Biol. 2010, 10: 183.

103. Shenk, P.M., Kazan, K., Wilson, I., Anderson, J., Richmon, T., Somerville, S.C., and Manners, 
J.M. Coordinated plant defense responses in Arabidopsis revealed by microarray analysis. Proc. Natl.Acad.Sci.USA. 2000, 97: 11655-11660.

104.Shiloh, Y. The ATM-mediated DNA-damage response: Taking shape. Trends Biochem. Sci. 2006, 31: 402-410.

105. Shinohara, A., Ogawa, H., and Ogawa, T. RAD51 involved in repair and recombination in Saccharomyces cerevisiea is a Rec-like protein. Cell 1992, 69: 457-470.

106. Smith, K.N., and Nicholas, A. Recombination at work for meiosis. Curr. Opin. Genet. Dev. 1998, 8: 200-211.

107. Song, F. and Goodman, R.M. OsBIMIK1, a rice MAP kinase gene involved in disease resistance responses. Planta 2002, 215: 997-1005.

108. Stojic, L., Brun, R., and Jiricny, J. Mismatch repair and DNA damage signaling. DNA Repair (Amst). 2004, 3: 1091-1101.

109. Stone, J.M., Heard, J.E., Asai, T., and Ausubel, F.M. Simulation of fungal-mediated cell death by fumonisin B1 and selection of fumonisin B1-resistant (fbr) Arabidopsis mutants. Plant Cell. 2000, 12: 1811-1822.

110. Swidzinski, J.A., Sweetlove, L.J., and Leaver, C.J. A custom microarray analysis of gene expression during programmed cell death in Arabidopsis thaliana. Plant J. 2002, 30: 431-446.

111. Takahashi, Y., Nasir, K.H.B., Ito, A., Kanzaki, H., Matsumura, H., Saitoh, H., Fujisawa, S., Kamoun, S., and Terauchi, R. A high-throughput screen of cell-death-inducing factors in Nicotiana benthamiana identifies a novel MAPKK that mediates INF1-induced cell death signaling and non-host resistance to Pseudomonas cichorii. Plant J. 2007, 49: 1030-1040. 
112. Tang, X.Y., Frederick, R.D., Zhou, J.M., Halterman, D.A., Jia, Y.L., and Martin, G.B. Initiation of plant disease resistance by physical interaction of Avrpto and Pto kinase. Science. 1996, 274: 2060-2063.

113. Van Doorn, W.G. Classes of programmed cell death in plants, compared to those in animals. J. Exp. Bot. 2011, 62: 4749-4761.

114. Watanabe, N. and Lam, E. Arabidopsis Bax inhibitor-1functions as an attenuator of biotic and abiotic types of cell death. Plant J.2006, 45: 884-894.

115. Wyllie, A.H. Glucocorticoid-induced thymocyte apoptosis is associated with endogenous endonuclease activation. Nature. 1980, 284: 555-556.

116. Xing, T. and Jordan, M. Genetic engineering of plant signal transduction mechanisms. Plant Mol. Biol. Rep. 2000, 18: 309-318.

117. Xing, T., Ouellet. T., and Miki, B.L. Towards genomic and proteomic studies of protein phosphorylation in plant-pathogen interaction. Trends Plant Sci. 2002, 7(5) :224-230.

118. Xing, T., Fan, T., Han, S.Y., Djuric-Ciganovic, S., Jordan, M., and Wang, X.J. Programmed cell death in plant disease resistance: pathways and components. Recent Res. Devel. Bioener. 2005, 3: 33-44.

119. Xing, T. 2007. Signal transduction pathways and disease resistant genes and their applications to fungal disease control. In: Biotechnology and Plant Disease Management, (Punja Z.K., Be Boer S.H., Sanfaçon H. ed.), pp 1-15, CAB International, UK.

120. Xing, T. and Laroche, A. Revealing plant defense signaling getting more sophisticated with phosphoproteomics. Plant Signal \& Behav. 2011, 6: 1-6.

121. Xiong, L. and Yang, Y. Disease resistance and abiotic stress tolerance in rice are inversely modulated by abscisic acid-inducible mitogen-activated protein kinase. Plant Cell. 2003, 15(3): 
745-759.

122. Yang, K, Liu, Y., and Zhang, S. Activation of a mitogen-activated protein kinase pathway is involved in disease resistance in tobacco. Proc. Natl. Acad. Sci. USA. 2001, 98: 741-746.

123. Yang, Y. and Xiong, L. Mitogen-activated protein kinase and method of use to enhance biotic and abiotic stress tolerance in plants. US Patent. 2008, NO.: US7, 345,219 B2.

124.Yuan, Y., Zhong, S., Li, Q., Zhu, Z., Lou, Y., Wang, L., Wang, J., Wang, M., Yang, D., and

He, Z. Functional analysis of rice NPR1-Like genes reveals that OsNPR1/NH1 is the rice orthologue conferring disease resistance with enhanced herbivore susceptibility. Plant Biotech. J. 2007, 5: 313-324.

125. Zhang, S., Liu, Y., and Klessig, D.F. Multiple levels of tobacco WIPK activation during the induction of cell death by fungal elicitins. Plant J. 2000, 23: 339-347.

126. Zhang, S. and Klessig, D.F. MAPK cascades in plant defense signaling. Trends Plant Sci. 2001, 6: 520-527.

127. Zhang, S. and Liu, Y. Activation of salicylic acid-induced protein kinase. A mitogen activated-protein kinase, induces multiple defense responses in tobacco. Plant Cell. 2001, 13: 1877-1889.

128. Zhou, S., Cui, Z., and Urban, J. Dead cell counts during serum cultivation are underestimated by the fluorescent live/dead assay. Biotechnol. J. 2011, 6: 513-518. 